\title{
Microstructure and compositional changes across biotite-rich reaction selvedges around mafic schollen in a semipelitic diatexite migmatite
}

\author{
Lina Lin (i) | Edward W. Sawyer
}

Département des Sciences Appliquées, Université du Québec à Chicoutimi,

Chicoutimi, QC, Canada

\section{Correspondence}

Lina Lin, Département des Sciences Appliquées, Université du Québec à Chicoutimi, Chicoutimi, QC, Canada.

Email: lina.lin1@uqac.ca

Handling Editor: Doug Robinson

\begin{abstract}
Biotite-rich selvedges developed between mafic schollen and semipelitic diatexite in migmatites at Lac Kénogami in the Grenville Province of Quebec. Mineral equilibria modelling indicates that partial melting occurred in the mid-crust (4.8-5.8 kbar) in the range $820-850^{\circ} \mathrm{C}$. The field relations, petrography, mineral chemistry and wholerock composition of selvedges along with their adjacent mafic schollen and host migmatites are documented for the first time. The selvedges measured in the field are relatively uniform in width $(\sim 1 \mathrm{~cm}$ wide) irrespective of the shape or size of their mafic scholle. In thin section, the petrographic boundary between mafic scholle and selvedge is defined by the appearance of biotite and the boundary between selvedge and diatexite by the change in microstructure for biotite, garnet, plagioclase and quartz. Three subtypes of selvedges are identified according to mineral assemblage and microstructure. Subtype I have orthopyroxene but of different microstructure and $M g \#$ to orthopyroxene in the mafic scholle; subtype II contain garnet with many mineral inclusions, especially of ilmenite, in contrast to garnet in the diatexite host which has few inclusions; subtype III lack orthopyroxene or garnet, but has abundant apatite. Profiles showing the change in plagioclase composition from the mafic schollen across the selvedge and into the diatexite show that each subtype of selvedge has a characteristic pattern. Four types of biotite are identified in the selvedges and host diatexite based on their microstructural characteristics. (a) Residual biotite forms small rounded red-brown grains, mostly as inclusions in peritectic cordierite and garnet in diatexite; (b) selvedge biotite forms tabular subhedral grains with high respect ratio; (c) diatexite biotite forms tabular subhedral grains common in the matrix of the diatexite; and (d) retrograde biotite that partially replaces peritectic cordierite and garnet in the diatexite. The four groups of biotite are also discriminated by their major element (EMPA) and trace elements (LA-Q-ICP-MS) compositions. Residual biotite is high in $\mathrm{TiO}_{2}$ and low in $\mathrm{Sc}$ and $\mathrm{S}$, whereas retrograde biotite has high $\mathrm{Al}_{2} \mathrm{O}_{3}$, but low $\mathrm{Sc}$ and $\mathrm{Cr}$. Selvedge and diatexite biotite are generally very similar, but selvedge biotite has higher Sc and $\mathrm{S}$ contents. Whole-rock compositional profiles across the selvedges constructed from micro-XRF and LA-Q-ICP-MS analyses show: (a) $\mathrm{Al}_{2} \mathrm{O}_{3}$, $\mathrm{FeO}, \mathrm{MgO}$ and $\mathrm{CaO}$ all decrease from mafic scholle across the selvedge and into the
\end{abstract}


diatexite; (b) $\mathrm{Na}_{2} \mathrm{O}$ is lowest in the mafic scholle, rises through the selvedge and reaches its maximum about $20-30 \mathrm{~mm}$ into the diatexite host; (c) $\mathrm{K}_{2} \mathrm{O}$ is lowest in the mafic scholle and reaches its highest value in the first half of the selvedge, then declines before reaching a higher, but intermediate value, about $20 \mathrm{~mm}$ into the diatexite. Of the trace elements, $\mathrm{Cs}$ and $\mathrm{Rb}$ show distributions very similar to $\mathrm{K}_{2} \mathrm{O}$.

K E Y W O R D S

biotite selvedge, chemical exchange, mafic schollen, semipelitic diatexite

\section{1 | INTRODUCTION}

The pelitic, greywacke and granitic rocks in metamorphic terranes may begin to melt when the temperature surpasses $\sim 650^{\circ} \mathrm{C}$ and form migmatites. Partial melting changes the system from a single phase, solid (rock) state, to a two-phase material consisting of a solid and a melt; this brings about major petrological and morphological changes. The melt is less viscous and dense than the solid fraction and hence is able to deform, or flow, at a faster rate than the solid. Therefore, melt can separate, or segregate, from the solid fraction under a suitable driving force, such as gravity or differential stress. Partial melting reactions typically result in the enrichment of components such as $\mathrm{FeO}, \mathrm{MgO}, \mathrm{Al}_{2} \mathrm{O}_{3}$ and $\mathrm{CaO}$ in the residual solids with $\mathrm{SiO}_{2}, \mathrm{~K}_{2} \mathrm{O}, \mathrm{Na}_{2} \mathrm{O}$ and $\mathrm{H}_{2} \mathrm{O}$ partitioned into the melt fraction. Thus, new heterogeneities created by partial melting and melt segregation add to any compositional heterogeneities, such as marble layers or mafic dykes, that predate partial melting. Segregation, which may be incomplete, and movement of the melt fraction enables compositionally very different materials to come into contact. For example, a metamafite, or marble layer can, at this stage, come into contact with the segregated anatectic melt, or even with the residual parts of the migmatite. The contacts between rocks of very different compositions within a migmatite are likely to be out of chemical equilibrium and exchanges will occur between them. Thus, the petrogenesis of migmatites can be viewed as the sum of the three processes: (a) partial melting of the protolith, (b) partial or complete segregation of melt from residuum and melt movement in the migmatite and (c) chemical exchange between juxtaposed, compositionally dissimilar, parts of the migmatite.

Partial melting has been studied in detail through melting experiments on a variety of rock types (Acosta-Vigil \& London, 2006; Conrad, Nicholls, \& Wall, 1988; Patino Douce \& Beard, 1995; Skjerlie, Patino Douce, \& Johnston, 1993), thermodynamic modelling in various systems (Johnson \& Brown, 2004; Palin, White, \& Green, 2016) and through field and petrological studies (Jones \& Brown, 1990; Otamendi \& Patino Douce, 2001; Sawyer, Cesare, \& Brown, 2011). Similarly, melt segregation has been investigated through experiments on analogue materials (Barraud, Gardien, Allemand, \& Grandjean,
2004; Rosenberg \& Handy, 2000) and rocks (Kohlstedt, King, \& Holtzman, 2010; Rutter \& Neumann, 1995), by numerical modelling (Hier-Majumder, Ricard, \& Bercovici, 2006; Simakin \& Talbot, 2001; Stevenson, 1989), and by field-based (Hall \& Kisters, 2016; Johnson, Hudson, \& Droop, 2001; Sawyer, 2001; Weinberg, Hasalová, Ward, \& Fanning, 2013; Weinberg \& Mark, 2008) and petrological (Holness \& Watt, 2002; Sawyer, 2014) studies. In marked contrast, the changes in microstructure and composition that resulted from chemical exchanges between compositionally different parts of migmatites have not yet been studied in detail. Thus, although their importance has been recognized (Cenki, Kriegsman, \& Braun, 2002; Kriegsman, 2001; White \& Powell, 2010), they remain the least understood of the three processes involved in the formation and development of migmatites. This is surprising because the evidence for chemical exchange between compositionally different parts in migmatites is widely reported, typically with a few words in the field description, or a figure caption. The most common manifestation of chemical exchange in migmatites is the presence of a narrow rim, or selvedge of different mineralogy, bulk composition and microstructure between adjacent, dissimilar parts (Figure 1a-d). Sawyer (2008) shows outcrop images that convey the variety of selvedges found in migmatites. However, from the images and brief descriptions in the literature, two types of selvedges appear to be most prevalent. Most commonly selvedge occurs as a narrow (typically $<5 \mathrm{~mm}$ ) dark, biotite-rich layer between leucosomes, or granitic veins (formerly melt-rich part), and the residuum and palaeosome (melt-poor and non-melted respectively) parts. Such biotite selvedges appear to be particularly common next to stromatic leucosomes (Genier, Bussy, Epard, \& Baumgartner, 2008; Hinchey \& Carr, 2006; Johnson, Fisher, White, Brown, \& Rollinson, 2012), but also occur next to discordant leucosomes and granitic veins (Carvalho, Sawyer, \& Janasi, 2016; Diener, White, \& Hudson, 2014). Early descriptions equated these narrow selvedges with residuum and melanosome (Ashworth, 1976; Johannes, Holtz, \& Möller, 1995; Obata, Yoshimura, Nagakawa, Odawara, \& Osanai, 1994; Price \& Taylor, 1977; Wickham, 1987), but more recent reports (Carvalho et al., 2016; Diener et al., 2014; Lavaure \& Sawyer, 2011; Morfin, Sawyer, \& Bandyayera, 2013, 2014) attribute their formation to reaction between melt and the wall rock. The other commonly 

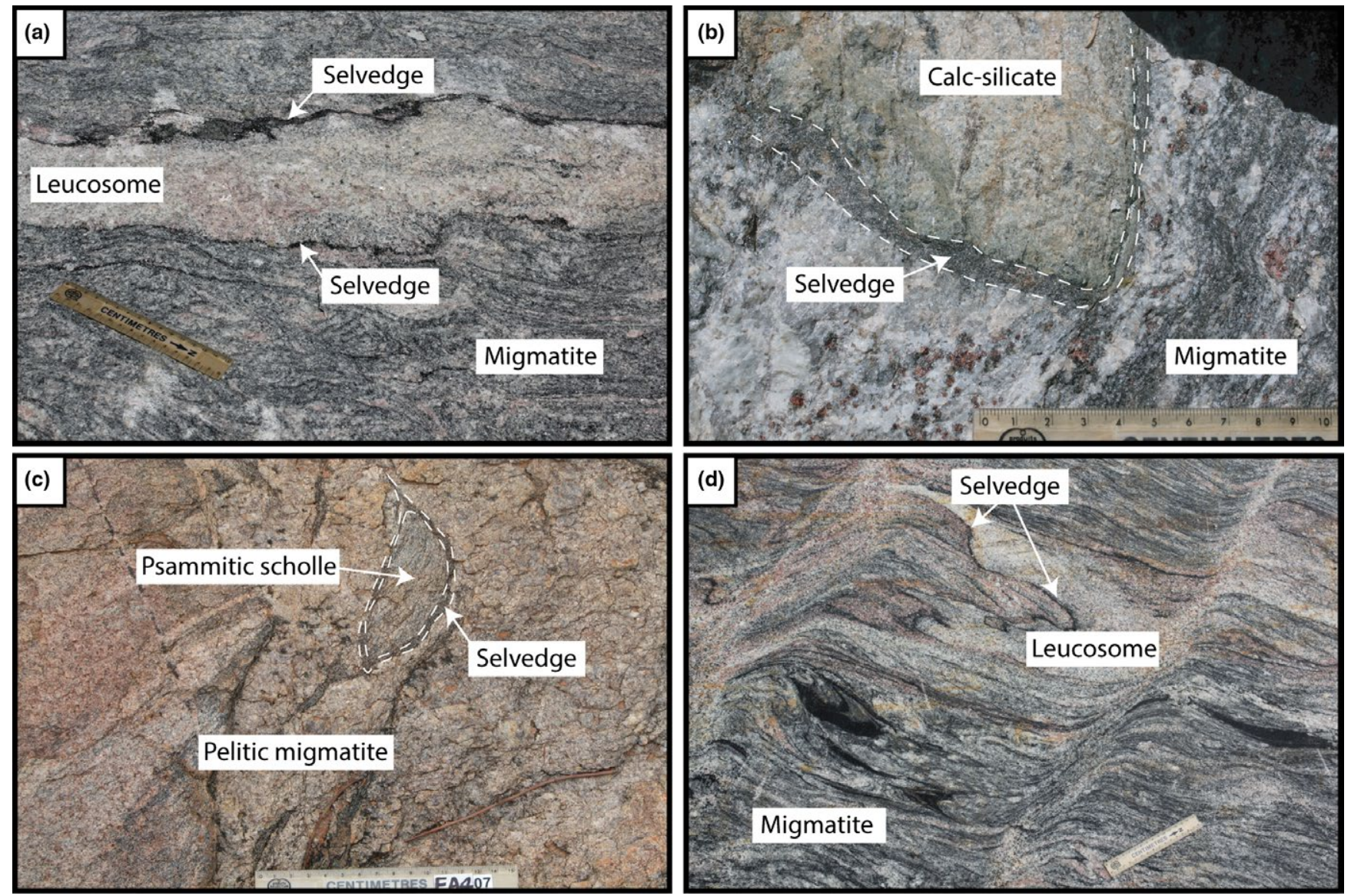

F I G URE 1 Examples of the types of selvedge found in migmatites. (a) Thin biotite selvedge at both sides of leucosomes in migmatite; Knawa Quarry, Brazil. (b) Melanocratic selvedge developed between a marble scholle and host pelitic diatexite; Socorro-Guaxupé Nappe, Brazil. (c) Melanocratic selvedge around a psammitic scholle in pelitic migmatite; Aus migmatite, Namibia. (d) Partial biotite selvedge established along wavy contact between leucosome and host migmatite; Knawa Quarry, Brazil

reported type of selvedge is also rich in biotite, but occurs as a much wider (up to $10 \mathrm{~cm}$ ) and compositionally zoned rim between diatexite (melt-rich part) and schollen within it. Mafic schollen are prone to developing this kind of selvedge (Troll \& Winter, 1983; Carvalho, Sawyer, \& Janasi, 2017; this study), but they also develop around schollen of marble (Figure 1a-d), calcsilicate, pelitic gneiss (Rocha, Moraes, Möller, Cioffi, \& Jercinovic, 2017) and residual (Johannes, Ehlers, Kriegsman, \& Mengel, 2003) bulk compositions. Troll and Winter (1983) examined the composition of biotite in such a selvedge and attributed its growth to reactions and chemical exchanges between the mafic schollen and surrounding melt-rich diatexite.

In spite of being common in migmatites, there are no detailed descriptions or documentation of the microstructure or compositional changes across, or within, selvedges that may be used to constrain and develop models of how they formed. Therefore, the objective of this study was to provide this baseline data by documenting the changes in macroscopic appearance, microstructure, mineral assemblage and the major and trace element compositions of the major minerals and bulk rock composition across the selvedges in a migmatite. In this contribution, we examine the selvedges formed around mafic schollen present in a semipelitic diatexite migmatite using petrography, image analysis, whole-rock XRF and ICP analyses combined with spot, line and area analyses using micro-XRF, electron microprobe and LA-Q-ICP-MS analysis techniques. Although these are not the most common type of selvedge generally found in migmatites, we study this type first for two reasons. (a) They are sufficiently wide that it is possible to obtain samples large enough that representative bulk analyses can be obtained to determine the changes in whole-rock composition across the selvedges. (b) In the migmatite studied, these are, because of their appreciable width, volumetrically the most important type of selvedge. Mass balance and petrogenetic modelling of how these selvedges developed will be presented in another contribution.

\section{$2 \mid$ GEOLOGICAL SETTING}

The study area (Figure 2 inset) in the Saguenay region lies within the Central Granulite Terrain (Wynne-Edwards, Price, 


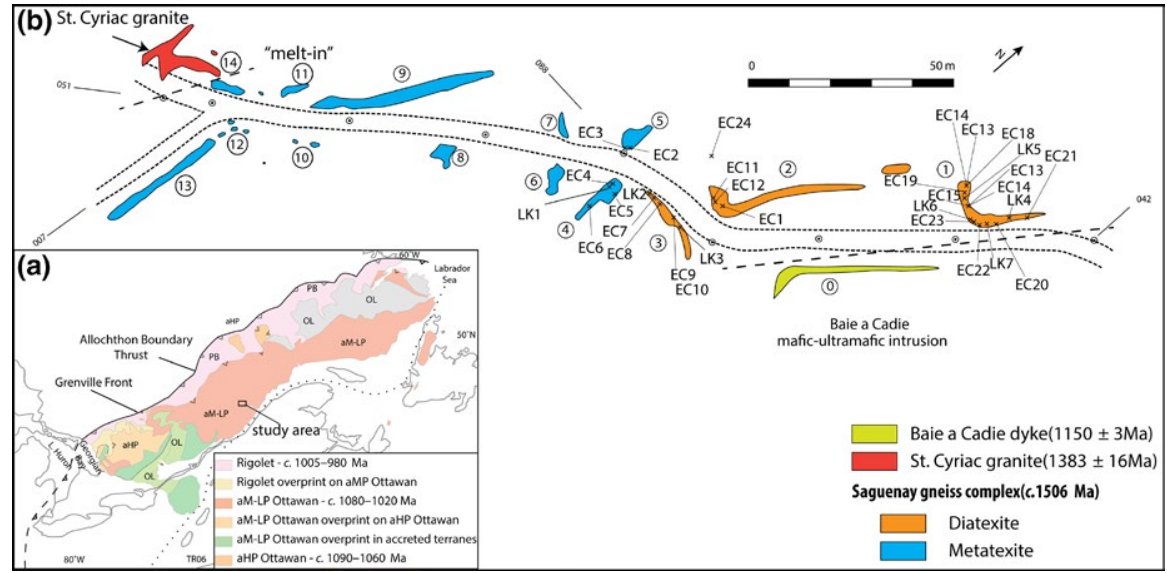

F I G URE 2 (a) Inset map showing the large-scale divisions of the Grenville Province after Rivers (2008) and the location of study area in the central Quebec. (b) Geological outcrop map of the contact metamorphic migmatite derived from semipelitic rocks belonging to the Saguenay Gneiss Complex at Lac Kenogami. Sample locations are indicated. Outcrop localities are denoted by circled numbers
\& Douglas, 1972) of the Grenville Province of Quebec in a domain referred as the allochthonous Medium Pressure Belt of the Laurentian margin and its accreted meso-Proterozoic terranes by Rivers et al. (2012). The geology of the Saguenay area is dominated by four suites of plutonic rocks. The oldest is largely granitic (now orthogneiss), whereas the other three are anorthosite-mangerite-charnockite-granite suites. Hébert, Cadieux, and Breemen (2005) dated the four suites at $1393 \mathrm{Ma}$, 1327 Ma, 1160-1135 Ma and 1082-1045 Ma respectively. The plutonic suites intrude an older basement termed the Saguenay Gneiss Complex which consists of plutonic and supracrustal rocks that have been intruded by mafic dykes dated as $1506 \mathrm{Ma}$ by Hébert et al. (2005), the minimum age for the basement in the Saguenay area. The supracrustal rocks in the Saguenay Gneiss Complex display a range of metamorphic grade and state of deformation. At St. Fulgence they occur in a wide, regional-scale dextral (the $>400 \mathrm{~km}$ long St. Fulgence Shear Zone) transpression zone (Hébert, Breemen, \& Cadieux, 2009; Rivers et al., 2012) and are strongly foliated, lineated and banded residual GrtCrd-Sil-Bt-Qz-Pl-Kfs metatexite migmatites (abbreviations for mineral names from Whitney and Evans (2010)) containing in situ and in-source garnet- and cordierite-bearing leucosomes. In our study area (Figure 2) at the northern edge of the St. Fulgence Shear Zone on the north shore of Lac Kenogami, psammitic and semipelitic metasediments containing foliated mafic dykes of the Saguenay Gneiss Complex were intruded first by the $1383 \mathrm{Ma}$ Saint Cyriac charnockite-mangerite, then again at $1150 \mathrm{Ma}$ (Hébert et al., 2005) by a 500-1,000 m wide mafic dyke belonging to the Baie à Cadie Suite. Intrusion of the latter caused anatexis in a narrow $(<50 \mathrm{~m})$ contact aureole in which the psammites and semipelites were changed to flow-banded diatexite migmatite that contains abundant mafic schollen.

\section{3 | ANALYTICAL METHODS}

An initial set of 23 samples (EC series) were collected for thin section petrography and whole-rock major and trace elements analysis. A further set of six samples (LK series) were carefully collected to contain mafic scholle, biotite-rich selvedge and the host diatexite so that the changes across the selvedges could be studied in detail.

Thin sections were made from the LK and EC series samples for petrographic examination and to obtain mineral compositions of the migmatites, selvedges and mafic schollen. Both point counting and image analysis using ImageJ were used to obtain modal proportions of the minerals present in the rocks; the results are given in Tables 1 and 2. Whole-rock compositions of the EC samples were determined by XRF and ICP-MS and for the LK samples by ICP-fusion (Table 3 and Table S1). Major element contents of plagioclase, Kfeldspar, sillimanite, cordierite, garnet, biotite, amphibole and orthopyroxene were obtained by electron microprobe analysis (Table 4 and Table S2). The trace element concentration in biotite was determined by laser ablation LA-Q-ICP-MS (Table S3). Bulk compositions of LK2 for constructing compositional profiles were obtained by Micro-XRF and LA-QICP-MS independently, results shown in Table S4 and Table $\mathrm{S} 5$ respectively. A detailed description of all the analytical procedures is given in Appendix S1.

\section{4 | MIGMATITES: FIELD ASPECTS}

\section{1 | Metatexites}

In the western section of the mapped area (Figure 2), the Saguenay Gneiss Complex farther than $\sim 18 \mathrm{~m}$ from the Baie à Cadie Suite mafic dyke is metatexite migmatite (Figure 3a). The sedimentary layers and rare mafic layers (highly transposed dykes) within it are evident and a strong foliation is developed parallel to the lithological layering. The psammitic and semipelitic layers contain conspicuous garnetbearing leucosomes up to $3 \mathrm{~cm}$ wide, most are stromatic, but some occur as diffuse patches and appear to have formed in situ. A $75 \mathrm{~cm}$ wide metamafic layer in the Saguenay Gneiss 
T A B L E 1 Modal composition of migmatites from EC series

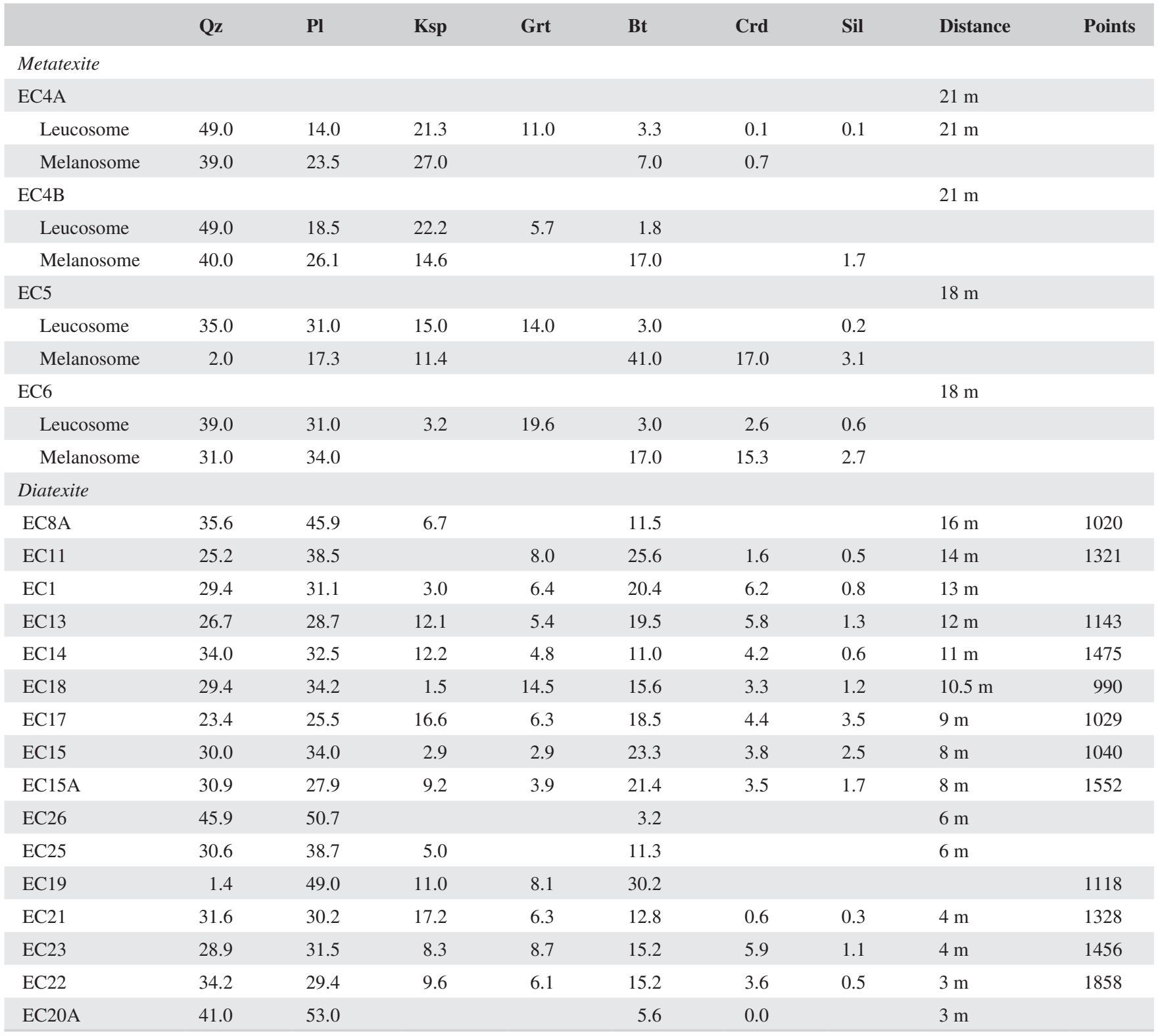

Distance - distance from Baie à Cadie dyke.

Complex (outcrop 5) shows local extension and thin leucosome is present in the shear bands which extend the layer.

\section{2 $\quad$ Diatexite}

The field appearance of the migmatites (Figure 3a-d) changes towards the Baie à Cadie Suite mafic dyke. At approximately $18 \mathrm{~m}$ from the dyke, the sedimentary and metamafic layers in the migmatite are no longer coherent but occur as isolated schollen in a coarse-grained grey host; the migmatite has become a diatexite (Figure 3b). Dark brownish-green schollen derived from mafic rocks are the most abundant and range in size from 2 to $70 \mathrm{~cm}$ (Figure $3 a-d)$. Schollen derived from the more refractory metasedimentary rocks, or from quartz veins, are rare and typically much smaller $(<10 \mathrm{~cm})$. Mafic schollen in the diatexite close to the transition from metatexite are tabular, contain an internal foliation and generally still aligned parallel to the direction of the original sedimentary layers and foliation in the metatexite; these schollen are from pre-anatectic metamafite dykes in the Saguenay Gneiss Complex. However, just $2 \mathrm{~m}$ closer to Baie à Cadie dyke, these schollen are rounded and equidimensional and variably rotated based on the orientation of their internal foliation. Closer still $(<15 \mathrm{~m})$ to the Baie à Cadie dyke, many mafic schollen have rounded, irregular almost lobate shapes and lack an internal foliation; these schollen may be small bodies of the intrusive Baie à Cadie dyke magma that 


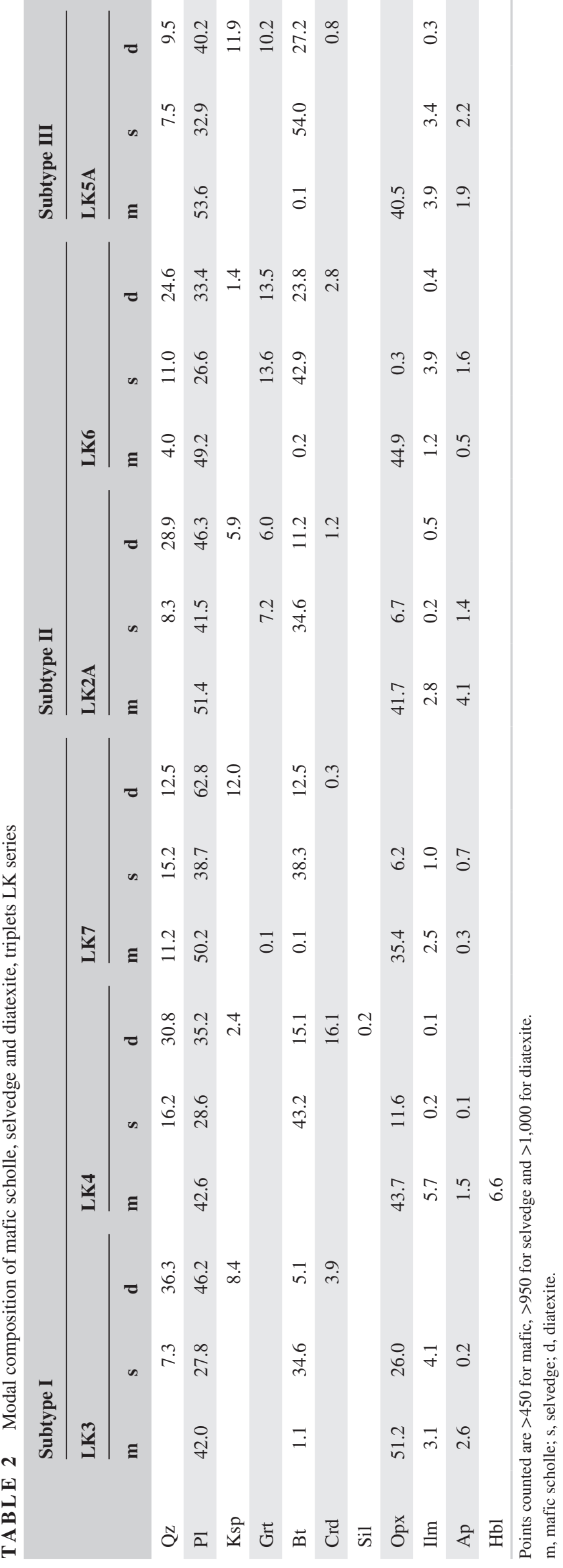

have become incorporated into the diatexite. Both types have mafic selvedges that are indistinguishable in the field.

The diatexite is heterogeneous and varies considerably in morphology and mineral mode. Most is a coarse-grained (3-7 mm) mesocratic grey rock that contains small porphyroblasts $(<15 \mathrm{~mm})$ of garnet and $\mathrm{K}$-feldspar in a matrix of cordierite + biotite + quartz + plagioclase + K-feldspar + ilmenite in which the tabular minerals are oriented and define a prominent foliation. Darker portions have higher modal biotite, cordierite or garnet and most of these are residual to some extent with EC19b the most residual; however, those with just high biotite contents may have a higher fraction of selvedge-derived material. Coarser grained, more leucocratic portions $(5-12 \mathrm{~mm})$ occur as thin, discontinuous layers and asymmetric lenses, typically $<5 \mathrm{~cm}$ wide, within the mesocratic diatexite and together with thin biotite schlieren, indicate a strong magmatic flow fabric in the diatexite. Triangular patches of leucosome or leucocratic diatexite occur on either side of the mafic schollen in the plane of the magmatic flow fabric and are interpreted as accumulations of anatectic melt in low pressure regions around the more rigid schollen. Leucosomes are rare and typically strongly attenuated (few mm wide) parallel to the magmatic flow fabric in the diatexite, but segments that are orthogonal to the flow fabric are wider and probably the last to form (up to $2 \mathrm{~cm}$ ).

The diatexite becomes coarser grained and more leucocratic (lower modal biotite) closer to the Baie à Cadie dyke (Figure 3d). In two places close to the contact (outcrops 1 and 3) with the Baie à Cadie dyke, veins of highly leucocratic diatexite (or leucosome) up to $20 \mathrm{~cm}$ wide intrude a few metres into the mesocratic diatexite away from the contact. These leucocratic rocks formed close to the Baie à Cadie dyke were hotter, less viscous and more mobile with notably larger $(6-12 \mathrm{~mm})$ euhedral crystals of plagioclase.

\section{3 | Biotite selvedges}

All the mafic schollen in the diatexite are enveloped by a dark, biotite-rich selvedge which isolates the metamafite from the diatexite host. Although the size of schollen ranges by a factor of $35(2-70 \mathrm{~cm})$, the selvedges are remarkably uniform in width (Figure 3a-d) irrespective of the size of the schollen they surround. Typically, selvedges are $\sim 1 \mathrm{~cm}$ wide and manifest as a weathered recess between the scholle and its diatexite host. Some schollen are considerably elongated in the direction of the magmatic flow structures in the diatexite, and the biotite selvedge around some of these schollen are wider in the pressure shadow region (Figure 3a-d) than perpendicular to it. In some cases, the wider portions (Figure 3c) contain an additional, morphological zone which contains more biotite and at its very outer edge, porphyroblasts of garnet. The absence of this distinctive outermost part of the selvedge along the long 
face of the scholle may indicate that it has been eroded away by flow of the diatexite past it. Some biotite schlieren in the diatexite can be traced back to the pointed ends of schollen and also suggests that selvedge material was removed during magmatic flow of the diatexite, i.e. by magmatic erosion.

The proportion of selvedges and schollen in the Lac Kenogami migmatites were determined from field measurements on 44 different mafic schollen and adjacent selvedges and analysis of photographs taken across outcrops 1, 2 and 3 on Figure 2. Although not uniformly distributed, mafic scholle comprise $16.1 \%$ and mafic selvedges $5.9 \%$ of the outcrop surface. Such large outcrop proportion of the selvedge underlines the necessity to understand the chemical exchange processes between hosting diatexite and schollen.

\section{5 | PETROGRAPHY}

\section{1 | Metatexite}

The typical mineral assemblage in the melanocratic parts of the metatexite is quartz + plagioclase + K-feldspar + biotite + cordierite + sillimanite, but the modal proportions vary from sample to sample (Table 1). The sample with lowest quartz has the highest cordierite content, thus some parts of the metatexite are more residual than others having undergone more melting and melt loss. Subhedral biotite and prismatic sillimanite define the foliation (Figure 4a). Most cordierite grains have a rim of biotite and fine-grained sillimanite with minor ilmenite along the biotite cleavage, but cordierite close to leucosomes is commonly completely replaced by these.

Leucosomes in the metatexite have the mineral assemblage quartz + plagioclase + K-feldspar + garnet + biotite; prismatic sillimanite and cordierite may also be present. Garnet generally occurs as scattered large porphyroblasts (Figure 4b) commonly with quartz inclusions. Table 1 indicates that cordierite occurs largely in the melanosomes and garnet largely in the leucosomes. Plagioclase in the melansome and leucosome from the same rocks have similar compositions but range from $\sim \mathrm{An}_{24}$ to $\sim \mathrm{An}_{30}$ from one sample to another.

\section{2 | Diatexite migmatites}

Typical diatexite (Figure 4c) has the mineral assemblage quartz + plagioclase $+\mathrm{K}$-feldspar + biotite + garnet + cordierite + sillimanite \pm ilmenite. Accessory phases, confirmed by energy dispersive microprobe analyses, in the diatexite are apatite, ilmenite, rutile, zircon, xenotime and monazite. Orthopyroxene occurs in two diatexite samples (EC19 and EC24) from closest to the Baie à Cadie dyke; these have very little biotite (Figure $4 \mathrm{~d}$ ). Table 1 shows that the modal proportions vary considerably among the diatexites. Some sillimanite occurs as inclusions in garnet, or else with large biotite flakes that comprise the schlieren. However, in most diatexites sillimanite occurs as small needles together with biotite in a narrow rim that partially replaces cordierite; thus, sillimanite in most diatexites is a retrograde phase. Sillimanite does not occur with orthopyroxene.

Biotite occurs in three microstructural contexts in the diatexites. (a) As small, rounded red-brown inclusions in garnet, cordierite and orthopyroxene, the ferromagnesian peritectic phases. (b) As coarse-grained, light-brown-coloured, euhedral to subhedral crystals in the matrix of diatexite; these are generally the most abundant type of biotite. (c) As partial or complete rims that replace the peritectic cordierite and garnet. This biotite is generally light brown, fine to medium grained and subhedral to anhedral in form and where cordierite is replaced, commonly intergrowth with small prismatic crystals of sillimanite. Hereafter, the three types will be referred to as residual, matrix and retrograde biotite respectively.

Tables 1 and 2 show that plagioclase is more abundant in the diatexites $(25-53 \%)$ than K-feldspar $(<16.6 \%)$. Many of the diatexites contain two morphologically different plagioclases. Most occurs as medium grained, subhedral crystals with weak zoning, well-developed albite twins and few inclusions (Figure 4d). However, some are rather larger, euhedral crystals with less well-developed twins and contain $~ 5 \%$ rectangular inclusions of quartz (Figure 4e).

\section{3 | Mafic scholle}

The interior of mafic schollen farthest from the enveloping biotite selvedge has the mineral assemblage plagioclase + orthopyroxene + ilmenite + apatite (Table 2). Plagioclase forms small $(0.3 \mathrm{~mm})$, polygonal, subhedral to anhedral crystals (Figure 5a). The orthopyroxene is fine-grained $(0.5 \mathrm{~mm})$ and occurs as anhedral, light-green to light-brown crystals (Figure 5a). The cores of a few mafic schollen contain anthophyllite some of which contain relics of orthopyroxene. Furthermore, the plagioclase in the orthamphibole-bearing scholle is altered to white mica; consequently, anthophyllite is considered to be a retrograde phase formed during minor rehydration. The composition of plagioclase varies from scholle to scholle, but all are calcic $\left(>\mathrm{An}_{70}\right)$.

\section{4 | Biotite-rich selvedges}

Modal analyses of the selvedges for the LK series samples are shown in Table 2 . The necessity to count a large area with $\sim 1,000$ points means that fine-scale variations in the selvedges are lost; consequently, the analysis represents the average for each selvedge. All the selvedges between the mafic scholle and diatexite contain abundant biotite (Figure 5b), some (LK5A) have as much as 54.4\%. Because biotite is abundant in all selvedges, absent from the mafic schollen and texturally different to the biotite in the diatexite, biotite is used to define the boundaries of the selvedges. The contact with the mafic scholle is defined 
TA B L E 3 Representative whole-rock composition

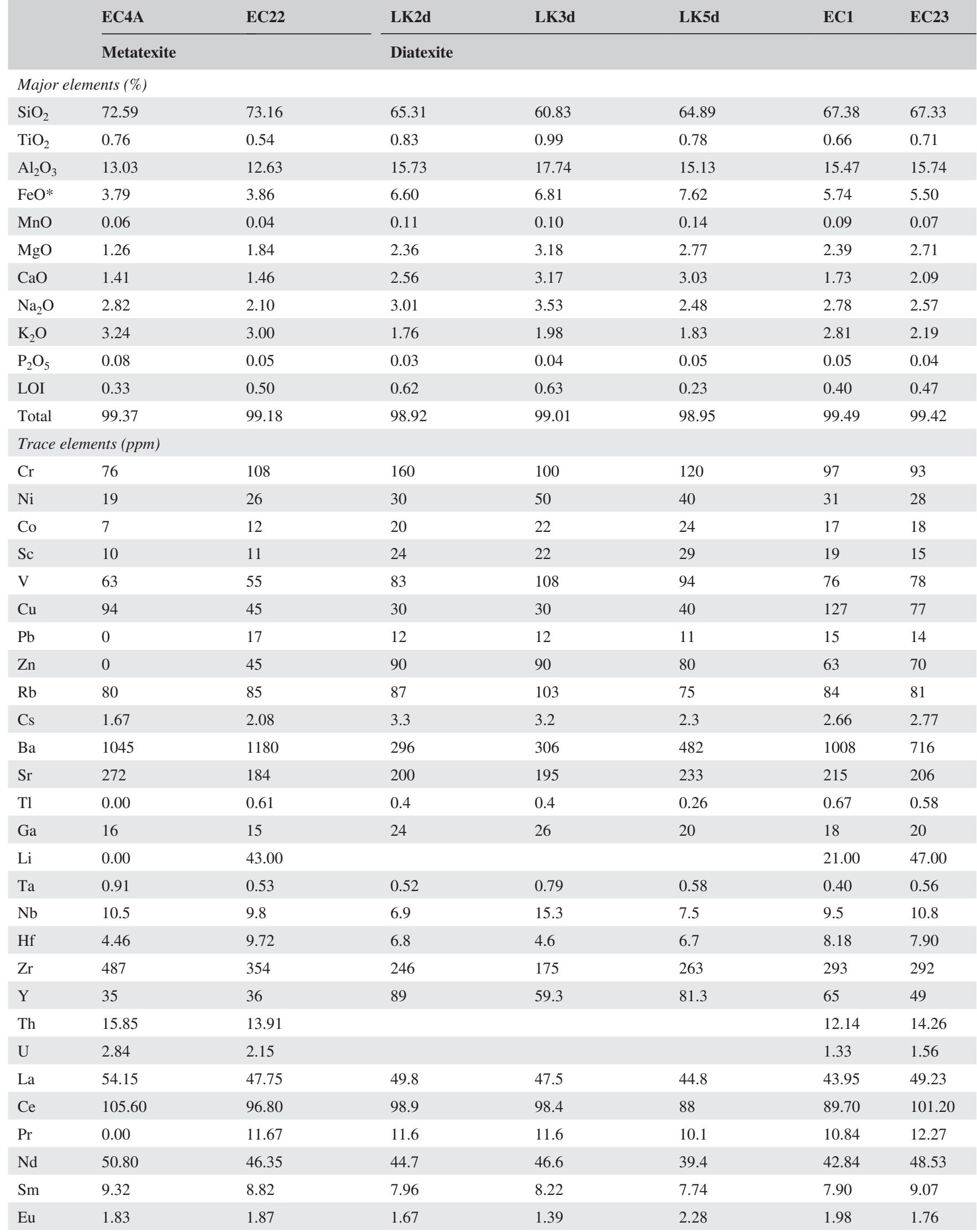




\begin{tabular}{|c|c|c|c|c|c|c|c|}
\hline LK2s & LK3s & LK4s & LK5s & EC3 & LK2 m & LK3 m & LK5 m \\
\hline 58.67 & 60.44 & 60.57 & 54.52 & 48.34 & 51.97 & 52.87 & 48.72 \\
\hline 0.82 & 0.92 & 1.01 & 2.25 & 2.40 & 1.01 & 1.15 & 2.56 \\
\hline 16.61 & 15.94 & 15.93 & 15.05 & 15.92 & 17.85 & 17.15 & 14.94 \\
\hline 0.11 & 0.08 & 0.09 & 0.13 & 0.26 & 0.20 & 0.18 & 0.31 \\
\hline 4.70 & 4.83 & 4.92 & 5.11 & 6.44 & 6.91 & 6.99 & 6.64 \\
\hline 5.21 & 2.85 & 4.06 & 5.49 & 8.99 & 8.02 & 7.65 & 6.42 \\
\hline 1.49 & 2.01 & 2.41 & 1.51 & 1.72 & 0.48 & 1.10 & 0.46 \\
\hline 98.08 & 98.49 & 100.01 & 98.22 & 99.41 & 99.07 & 99.62 & 98.95 \\
\hline 90 & 80 & 120 & 60 & 84 & 110 & 100 & 50 \\
\hline 50 & 50 & 70 & 70 & 98 & 80 & 40 & 60 \\
\hline 31 & 29 & 38 & 41 & 59 & 54 & 47 & 49 \\
\hline 23 & 19 & 26 & 28 & 31 & 35 & 32 & 40 \\
\hline 151 & 166 & 202 & 191 & 284 & 211 & 217 & 215 \\
\hline 20 & 10 & & 30 & 186 & 40 & & 30 \\
\hline 0.55 & 0.73 & 0.68 & 0.62 & 0.08 & 0.14 & 0.1 & 0.13 \\
\hline \multirow[t]{2}{*}{21} & 24 & 22 & 26 & 22 & 19 & 18 & 22 \\
\hline & & & & 19.70 & & & \\
\hline 0.55 & 0.89 & 0.91 & 1.23 & 0.47 & 0.11 & 0.23 & 0.48 \\
\hline 5.4 & 11.5 & 9.9 & 17.4 & 8.1 & 1.6 & 1.5 & 7.8 \\
\hline 2.6 & 1.9 & 2.2 & 7 & 4.13 & 2.6 & 2.2 & 6.9 \\
\hline 79 & 59 & 64 & 248 & 156 & 86 & 66 & 278 \\
\hline \multirow[t]{3}{*}{29.9} & 12.9 & 31.6 & 49.4 & 41 & 31.6 & 21.8 & 52.4 \\
\hline & & & & 1.66 & & & \\
\hline & & & & 2.10 & & & \\
\hline 25.9 & 19.6 & 19 & 53.8 & 15.35 & 4.92 & 4.15 & 17.2 \\
\hline 55 & 42.4 & 42.1 & 123 & 37.90 & 12.5 & 9.95 & 44.5 \\
\hline 6.66 & 5.05 & 5.26 & 15.7 & 5.52 & 1.87 & 1.44 & 6.56 \\
\hline 26.4 & 20 & 21.8 & 67.2 & 26.26 & 10.6 & 7.28 & 32 \\
\hline 6.08 & 4.6 & 5.74 & 17.6 & 6.71 & 3.49 & 2.29 & 8.72 \\
\hline 1.25 & 0.809 & 1.35 & 2.54 & 1.99 & 1.29 & 1.02 & 2.56 \\
\hline
\end{tabular}


T A B LE 3 (Continued)

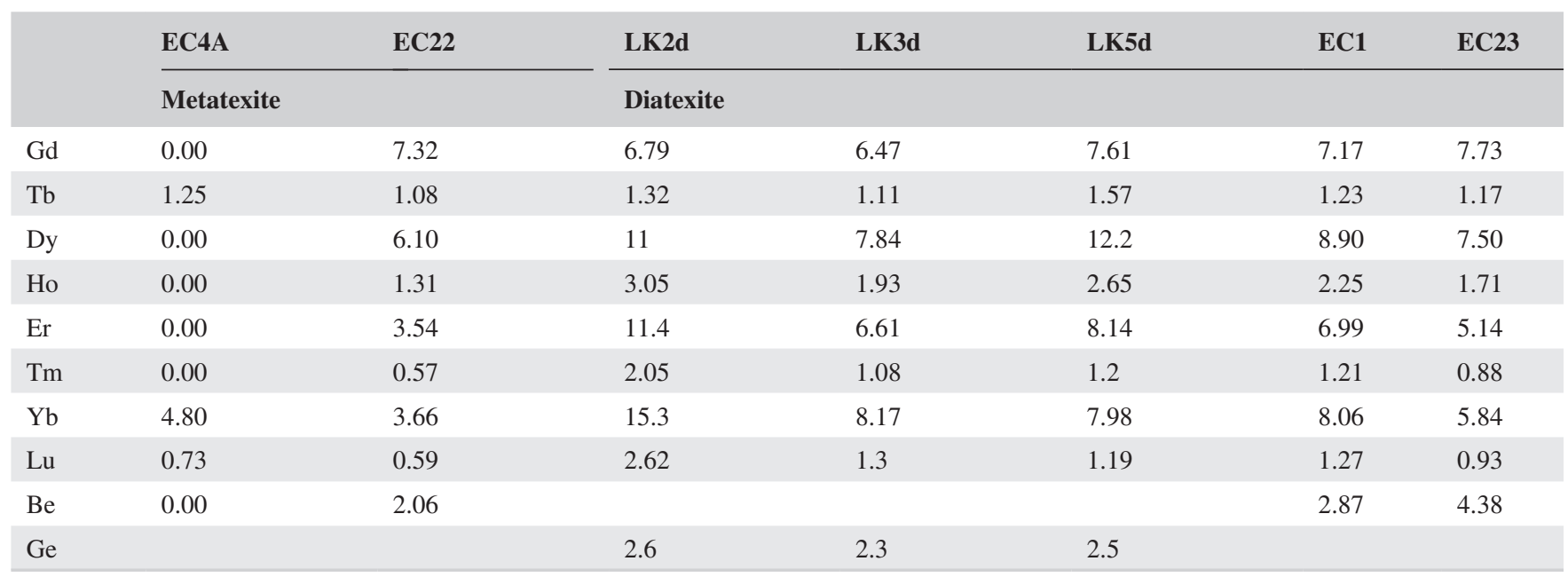

as where biotite first appears. A thin $(1 \mathrm{~mm})$ band of plagioclase (Figure 4f) is also developed subparallel to the boundary in a few samples; in some it is on the scholle side, whereas in others on the selvedges side of the first appearance of biotite. The outer edge of the biotite selvedge against diatexite is marked by a change of microstructure, specifically (a) the modal proportion of biotite declines abruptly, (b) the morphology of biotite changes to a lower aspect ratio and (c) there is a marked increase in the grain size and mode of quartz and feldspar.

All selvedges contain brown euhedral to subhedral biotite of high aspect ratio (hereafter selvedge biotite), subhedral to anhedral plagioclase, anhedral irregular-shaped quartz and a minor amount of anhedral ilmenite (Table 1). Subhedral plagioclase tends to be equant and of uniform size, whereas the anhedral plagioclase is irregular in shape and size. Although the principal minerals are the same, variations in the microstructure and mineral assemblage occur among the selvedges and three subtypes are identified.

Subtype I selvedges have the assemblage biotite + plagioclase + quartz + ilmenite + orthopyroxene. Orthopyroxene occurs throughout the selvedge and is readily differentiated from that in the adjacent mafic scholle (Figure 5c) because it is 5-10 times larger, may have crystal faces and contains inclusions of biotite, plagioclase and quartz. The width of this type of selvedge is $\sim 7 \mathrm{~mm}$.

Subtype II selvedges have the mineral assemblage of biotite + plagioclase + quartz + ilmenite + orthopyroxene + garnet. The key feature is the presence of both orthopyroxene and garnet. Unlike subtype I, the orthopyroxene shows no textural difference from that in the adjacent mafic scholle and may persist to about half way across the selvedge. Garnet in these selvedges occurs near the contact with diatexite and is poikiloblastic with abundant ( 20\%) inclusions of biotite, plagioclase, quartz and ilmenite (Figure 5d). Most of this garnet is considered to have grown during the selvedge-forming process and may have overgrown a small peritectic garnet seed in the diatexite. This is because ilmenite is ubiquitous in the mafic scholle ( $\sim 2$ modal $\%$ ), but occurs only in trace amount in the diatexite and garnet (Figure 5e) in the diatexite far from selvedges contain few, or no inclusions of ilmenite. Subtype II selvedges are $\sim 10 \mathrm{~mm}$ wide using selvedge biotite and ilmenite-bearing garnet to define its inner and outer boundaries. This is the commonest type of biotite selvedge.

Subtype III selvedges have the mineral assemblage biotite + plagioclase + quartz + ilmenite + apatite. They are distinguished by the absence of orthopyroxene and garnet, but high abundance of apatite and biotite. These selvedges are $\sim 8 \mathrm{~mm}$ wide and rarest among the samples collected.

Subtype I selvedges have the lowest modal content (Table 2$)$ of apatite $(0.1-0.7 \%)$, subtype II an intermediate amount (1.4-1.6\%) and subtype III the highest abundance of apatite $(2.2 \%)$. Thus, apatite mode appears to correlate with subtype.

\section{WHOLE-ROCK COMPOSITIONS}

The whole-rock compositions (Table 3) are shown on bivariant plots (Figure $6 \mathrm{a}-\mathrm{h}$ ) in which the abscissa variable is $\mathrm{SiO}_{2}$ chosen to produce the largest spread in the data and separate mafic schollen from the semipelitic migmatites. The oxides and elements controlled by (e.g. $\mathrm{MgO}$, Co and $\mathrm{Sc}$ ) or mostly controlled by (e.g. $\mathrm{FeO}, \mathrm{MnO}, \mathrm{TiO}_{2}, \mathrm{Cr}$ and $\mathrm{V})$ the ferromagnesian silicate phases biotite, cordierite, garnet and orthopyroxene, show an overall negative correlation with $\mathrm{SiO}_{2}$. However, on closer inspection, the metatexite and diatexite migmatites form a trend (dashed line on Figure 6a,b) from the melanocratic diatexite EC19, rich in residual phases, to the melt-rich leucocratic diatexite 


\begin{tabular}{|c|c|c|c|c|c|c|c|}
\hline LK2s & LK3s & LK4s & LK5s & EC3 & LK2 m & LK3 m & LK5 m \\
\hline \multicolumn{4}{|c|}{ Selvedge } & \multicolumn{4}{|c|}{ Mafic } \\
\hline 0.98 & 0.54 & 1.01 & 2.53 & 1.16 & 0.89 & 0.59 & 1.65 \\
\hline 5.92 & 2.81 & 6.01 & 12.5 & 7.10 & 5.85 & 3.83 & 9.94 \\
\hline 0.382 & 0.171 & 0.445 & 0.547 & 0.59 & 0.489 & 0.36 & 0.779 \\
\hline 2.5 & 1.16 & 2.74 & 3.37 & 3.69 & 3.22 & 2.59 & 4.87 \\
\hline \multirow[t]{2}{*}{0.385} & 0.163 & 0.421 & 0.497 & 0.56 & 0.506 & 0.409 & 0.793 \\
\hline & & & & 1.43 & & & \\
\hline
\end{tabular}

EC26 that lies below the mafic schollen. A second trend is evident within the migmatites at high $\mathrm{SiO}_{2}$ content (see indicated by the green field extending from EC7 to EC26) which show a notable depletion in $\mathrm{FeO}$, Sc (Figure 6c,d) and $\mathrm{Cr}$ (also for other elements described below). All the samples showing such depletion are coarse-grained, meltrich leucocratic diatexites which intrude mesocratic diatexite close to the Baie à Cadie dyke. The depletion in $\mathrm{Cr}$ and $\mathrm{Sc}$ suggests that orthopyroxene was a peritectic phase in the residuum when these diatexites were generated. The mafic schollen have higher abundances of $\mathrm{FeO}, \mathrm{TiO}_{2}$, $\mathrm{MnO}, \mathrm{MgO}, \mathrm{Co}, \mathrm{Sc}, \mathrm{Cr}$ and $\mathrm{V}$ than the migmatites; $\mathrm{TiO}_{2}$ displays a particularly wide range from $\sim 1$ to $\sim 2.5 \mathrm{wt} \%$ in the schollen. The LK samples show that for these elements the mafic selvedges generally plot between their associated mafic schollen and diatexite hosts and are roughly collinear with them. However, the LK6 set is an exception and the selvedge contains more $\mathrm{TiO}_{2}, \mathrm{FeO}, \mathrm{Cr}, \mathrm{Ni}$ and $\mathrm{V}$ than its mafic scholle and diatexite; this may be related to the high modal proportion of ilmenite in that selvedge.

Although most diatexites have lower $\mathrm{Al}_{2} \mathrm{O}_{3}$ contents than the mafic schollen, the overall trend defined at low $\mathrm{SiO}_{2}$ by the melanocratic diatexite EC19, lies well above the mafic schollen. Sample EC19 contains a high modal proportion of cordierite and garnet and represents a residuum-rich diatexite and has lost much of its melt fraction.

Most diatexite samples have higher abundances of $\mathrm{K}_{2} \mathrm{O}$, $\mathrm{Rb}, \mathrm{Cs}, \mathrm{Pb}, \mathrm{Zr}, \mathrm{Hf}, \mathrm{Ta}, \mathrm{Nb}, \mathrm{Th}, \mathrm{U}$, and light rare earth elements (LREE) than the mafic schollen. However, the intrusive leucocratic diatexites close to the Baie à Cadie dyke form a group with much lower abundances of these elements (shown by green ellipse on Figure 6e,f) in addition to their low $\mathrm{FeO}, \mathrm{MgO}, \mathrm{Co}, \mathrm{Cr}$ and $\mathrm{Sc}$ contents. Selvedges generally have higher contents of $\mathrm{K}_{2} \mathrm{O}, \mathrm{Rb}$ and $\mathrm{Cs}$ than their associated diatexites, but Figure 6e,f show that the LK diatexites immediately adjacent to the selvedges have lower $\mathrm{K}_{2} \mathrm{O}$ and $\mathrm{Rb}$ contents than the EC series diatexites collected $>30 \mathrm{~cm}$ from the schollen. Thus, the selvedge-forming process appears to produce a significant depletion halo several centimetres wide in the surrounding diatexite for these elements.

The high field strength elements (HFSE) Hf, $\mathrm{Zr}$ (Figure 6g), Ta, Nb, Th (Figure 6h), U and LREE are in general more abundant in the diatexites than in the mafic schollen. However, the lowest abundances occur in the high silica leucocratic diatexites closest to the Baie à Cadie dyke. The HFSE show quite complex distribution in the selvedges. Some of the LK scholle-selvedge-diatexite triplet sets are essentially collinear, but in others the selvedges are strongly enriched (LK6) or strongly depleted (LK3) in the HFSE relative to the adjacent scholle and diatexite (Figure $6 \mathrm{~g}, \mathrm{~h}$ ). Both $\mathrm{Ta}$ and $\mathrm{Nb}$ tend to be highest in the selvedges. The heavy rare earth element (HREE) and Y contents of the diatexites and scholle are similar. However, four of six selvedges have lower HREE contents than either their associated scholle or diatexite.

The elements associated with plagioclase $\left(\mathrm{CaO}, \mathrm{Na}_{2} \mathrm{O}\right.$ and $\mathrm{Sr}$ ) show different distributions; $\mathrm{CaO}$ is higher in the mafic scholle, $\mathrm{Na}_{2} \mathrm{O}$ is higher in the diatexite but $\mathrm{Sr}$ has about the same abundance in both. In general, the $\mathrm{CaO}$ and $\mathrm{Na}_{2} \mathrm{O}$ contents of the selvedge are intermediate and roughly collinear between the adjacent scholle and diatexite with the notable exception of the LK6 set. However, all selvedges have lower $\mathrm{Sr}$ than the adjacent mafic scholle or diatexite.

The $\mathrm{P}_{2} \mathrm{O}_{5}$ content of the metatexite and diatexite migmatites distal to the schollen is lower $(\sim 0.05 \mathrm{wt} \%)$ than that of the mafic scholle ( $\sim 0.1$ to $>0.4 \mathrm{wt} \%)$ and changes little with $\mathrm{SiO}_{2}$ content. Two samples adjacent to selvedges, diatexite LK7 and scholle LK5, have anomalously high $\mathrm{P}_{2} \mathrm{O}_{5}$ contents (>0.8 wt\%); the latter also has anomalously high modal apatite.

The $\mathrm{Ba}$ of the metatexite and diatexites ranges from $<300$ to $>1,000 \mathrm{ppm}$ and is lowest in the leucocratic 


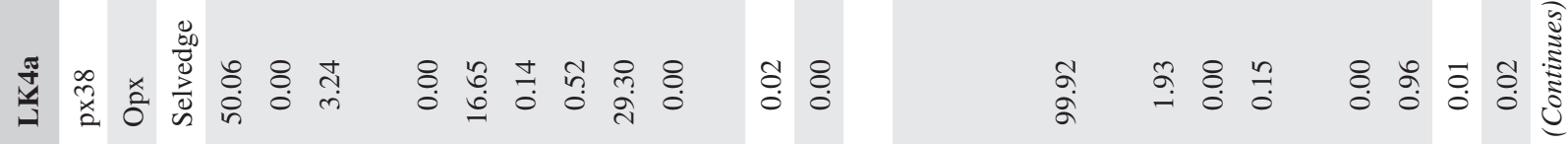

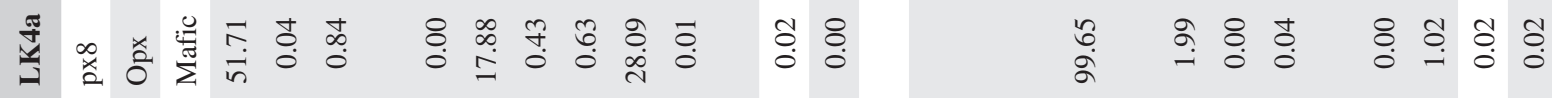

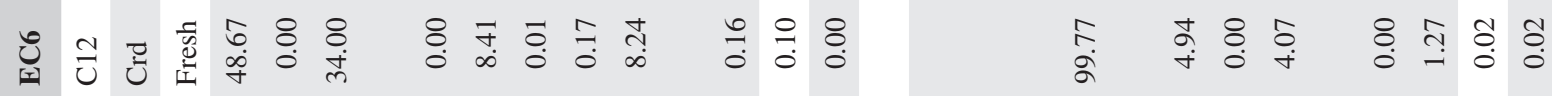

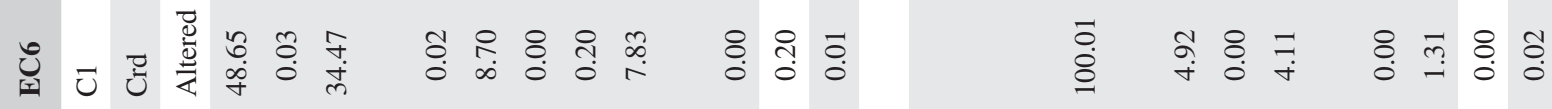

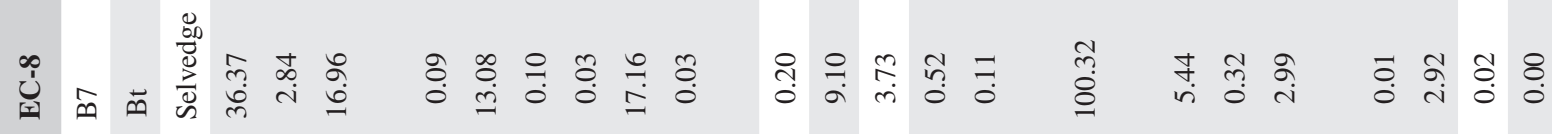

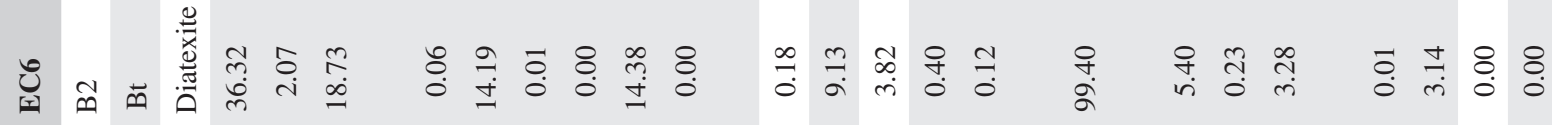

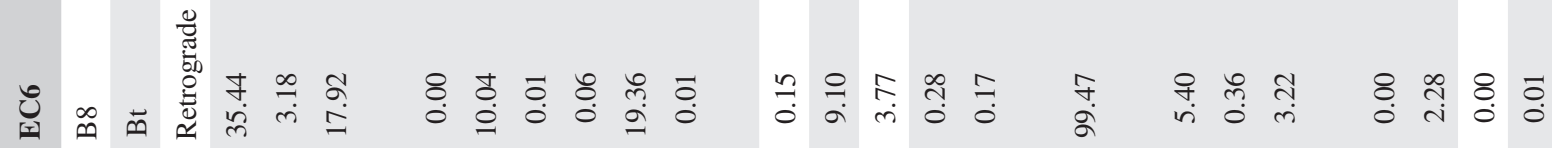

苗

$$
\stackrel{8}{3}
$$

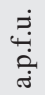

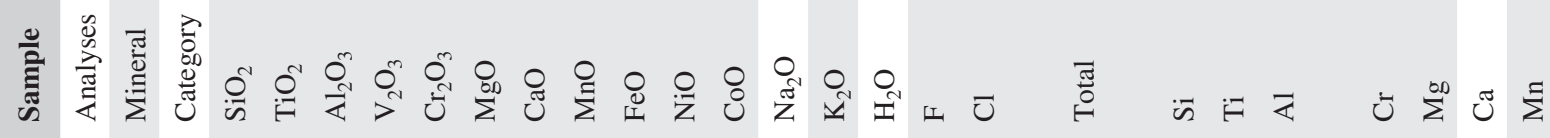

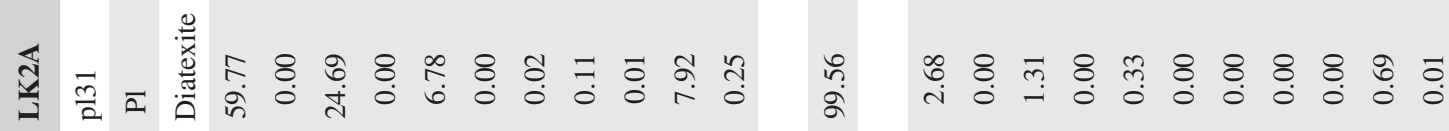

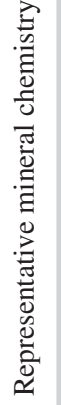

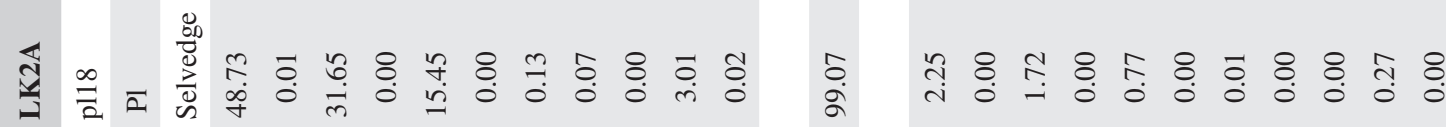

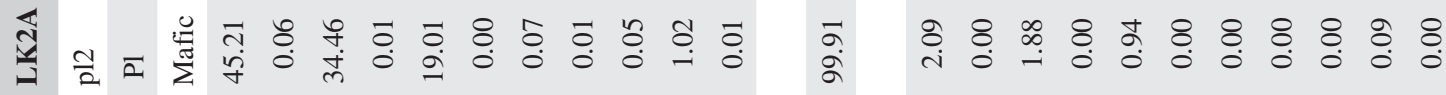

$\stackrel{8}{3}$

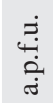

$\underset{4}{+}$

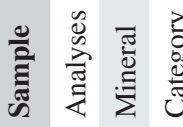

突

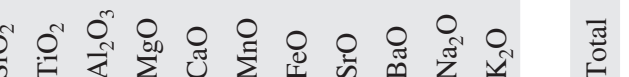

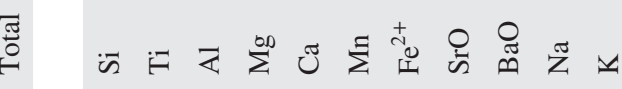




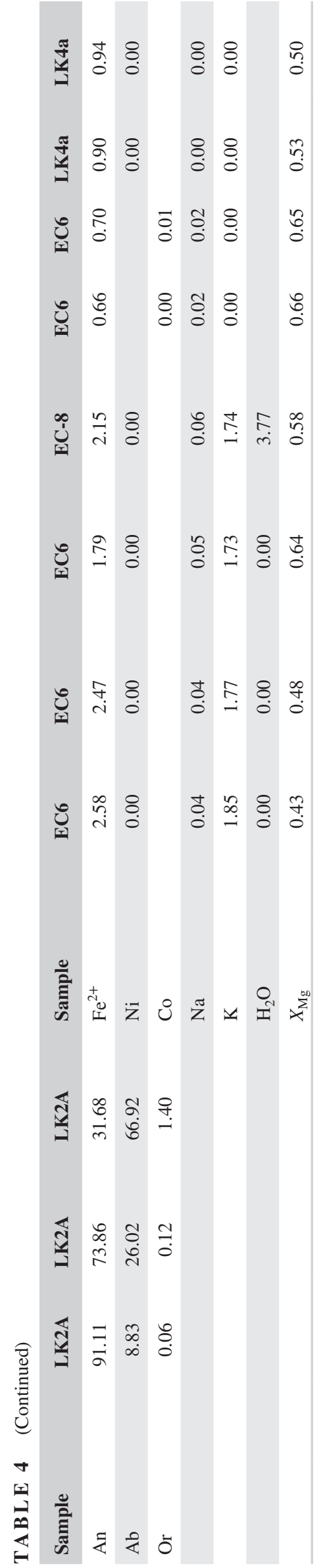

diatexites nearest to the Baie à Cadie dyke. The $\mathrm{Ba}$ in diatexite decreases close to the schollen as shown in Table 3 by the position of the LK series diatexite samples. The lowest $\mathrm{Ba}$ contents $(<200 \mathrm{ppm})$ are the mafic scholle as expected; however, some schollen have much higher $\mathrm{Ba}$ contents (400-2,200 ppm). In four of six scholle-selvedgediatexite sets, the mafic scholle has the highest $\mathrm{Ba}$ content and the diatexite the lowest, suggesting migration of $\mathrm{Ba}$ into the mafic scholle.

Chrondrite normalized rare earth element (REE) patterns for the migmatites, schollen and selvedges are shown in Figure $7 \mathrm{a}-\mathrm{h}$. Metatexites and diatexites have very similar REE patterns with LREE 100-200 times chondrite and the HREE 25-70 times and slight negative Eu anomalies (Figure 7a,b). The principal difference is that the pattern for the metatexites is flat from $\mathrm{Tb}$ to $\mathrm{Lu}$, whereas most diatexites show a concave pattern there with lower Tb to Er. The leucocratic diatexites have curved patterns with slightly lower LREE (20-100 times chondrite) patterns and much lower HREE and some (EC25 and 26) have strong positive Eu anomalies. The mafic schollen have lower smooth REE patterns at $\sim 20$ times chondrite, but some show LREE enrichment to $\sim 70$ times chondrite and a weak negative $\mathrm{Eu}$ anomaly.

The REE patterns from the schollen-selvedge-diatexite triplets are complex. The LK2 and LK3 sets are quite similar (Figure 7c,d); the schollen and diatexites have typical patterns and the selvedge lies between them in the LREE and middle rare earth elements (MREE) sections, but from Dy to $\mathrm{Lu}$ are depleted in HREE. The patterns for the triplets LK4, LK5 and LK6 also have similarities and show a progressive change in the MREE (Figure $7 \mathrm{e}-\mathrm{g}$ ). In the LK4 set, the diatexite has a marked trough in the MREE, whereas the scholle shows a slight increase in the MREE. The LK4 selvedge has intermediate LREE, higher MREE and lower HREE. Within the LK5 set, the scholle has an essentially smooth, LREE-enriched pattern and the diatexite shows a decrease from $\mathrm{Nd}$ to Dy. In contrast, the selvedge has higher LREE and MREE than either, but has lower HREE. Set LK6 is similar except that the selvedge has even higher LREE and MREE, and its HREE content is between that of the diatexite and scholle. In all three cases, the selvedge has a negative Eu anomaly due to the increase in LREE and MREE around Eu. The REE patterns for the LK7 set are different (Figure 7h); the diatexite has a strongly HREE-depleted pattern like the leucocratic diatexites close to the Baie à Cadie dyke (EC7 and 8 on Figure 7b). The LK7 selvedge has REE contents intermediate between the diatexite and mafic schollen, expect for Tb, Dy and Ho. Overall, the REE patterns of the LK sets suggest a loss of HREE and gain in MREE and LREE during the selvedge-making process; this suggests the formation of apatite and monazite. 

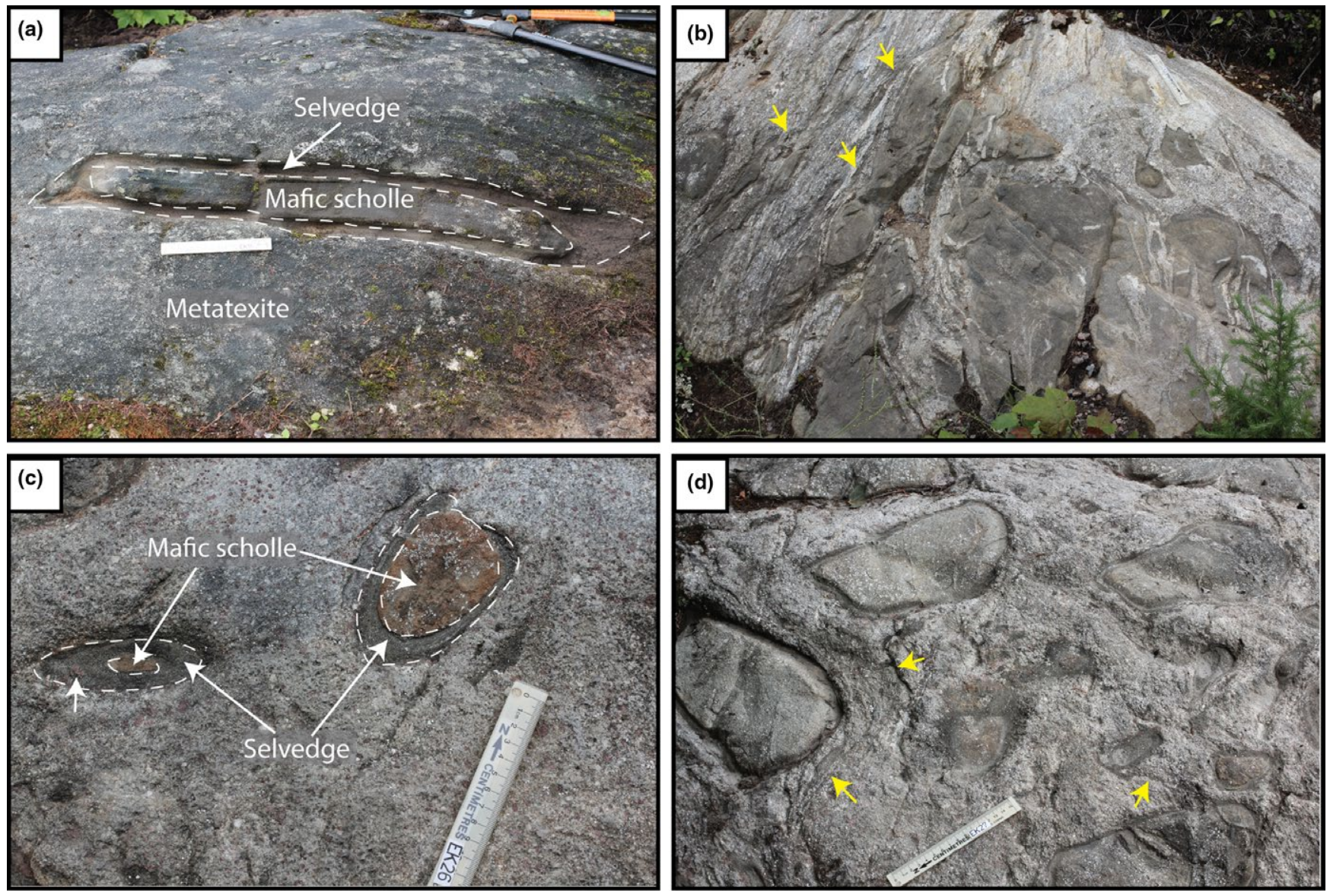

F I G U RE 3 Outcrop appearance of mafic schollen and the biotite selvedges developed between them and the host semipelitic migmatite at Lac Kenogami. (a) Rectangular, foliated mafic scholle from an old Saguenay Gneiss Complex mafic dyke in migmatite near metatexite-diatexite border at locality 4 , the long direction of the scholle is parallel to the foliation in the migmatite. Note that the biotite-rich selvedge is weathered back and is wider at the ends of the scholle than on its long faces. (b) Diatexite migmatite at locality 3, the magmatic flow fabric is defined by biotite schlieren (arrowed) and by layers of different modal mineralogy. The mafic schollen in this part of the migmatite range from tabular to rounded with long axes parallel to the local magmatic flow direction. (c) Small mafic schollen without internal foliation at locality 1 . These show a rounded core of metamafite surrounded by a biotite selvedge that is wider in the direction of the local flow foliation in the diatexite; this suggests that the selvedge may have been eroded. Note garnet crystals (arrowed) at the outside edge of the widest part of the selvedge, also that the schollen on the right is larger. (d) Mafic schollen (without internal foliation) of various shapes and sizes in diatexite at locality 1 13 m from the contact with the Baie à Cadie dyke, arrow indicates schlieren. Note the schlieren on lower left of the photo indicates the biotite selvedge was being eroded into diatexite. Regardless of the size and shape of mafic scholle, the selvedges all appear to be of similar width in outcrop. Scale in each image is $15 \mathrm{~cm}$ long

\section{7 | MINERAL EQUILIBRIA MODELLING}

Pseudosections showing the stable multivariant phase assemblages in a chosen model chemical system for a specific bulk composition can be used to estimate $P-T$ conditions and to understand metamorphic processes (Powell, Holland, \& Worley, 2004; White, Powell, \& Baldwin, 2008). The model system chosen to represent the Lac Kenogami migmatites is NCKFMASHTO $\left(\mathrm{Na}_{2} \mathrm{O}-\mathrm{CaO}-\mathrm{K}_{2} \mathrm{O}-\mathrm{FeO}-\mathrm{MgO}-\mathrm{Al}_{2} \mathrm{O}_{3}-\mathrm{SiO}_{2}-\right.$ $\mathrm{H}_{2} \mathrm{O}-\mathrm{TiO}_{2}-\mathrm{Fe}_{2} \mathrm{O}_{3}$ ), since it is presently the most realistic approximation to natural pelitic rock compositions (White, Powell, \& Holland, 2007). Calculations were undertaken with THERMOCALC 3.40i (Powell \& Holland, 1988) with the updated version of the Holland and Powell (2011) data set (ds62) and the recent $a$-x models developed for use in that system by White, Powell, Holland, Johnson, and Green (2014).

The bulk composition of a uniform and typical diatexite migmatite EC23 was modified slightly by converting a small amount of total $\mathrm{FeO}$ to $\mathrm{Fe}_{2} \mathrm{O}_{3}$, and then normalizing to the NCKFMASHTO system (Table 5). The $\mathrm{H}_{2} \mathrm{O}$ content was adjusted such that the rock is water saturated at the $5.5 \mathrm{kbar}$ solidus.

The prograde mineral assemblage in diatexite sample EC23 (location indicated on Figure 2) is biotite + plagioclase + quartz + garnet + cordierite + K-feldspar + ilmenite and corresponds to the field marked as $\mathrm{g} \mathrm{ksp} \mathrm{bi} \mathrm{cd}$ liq on the calculated $P-T$ pseudosection shown in Figure 8. 

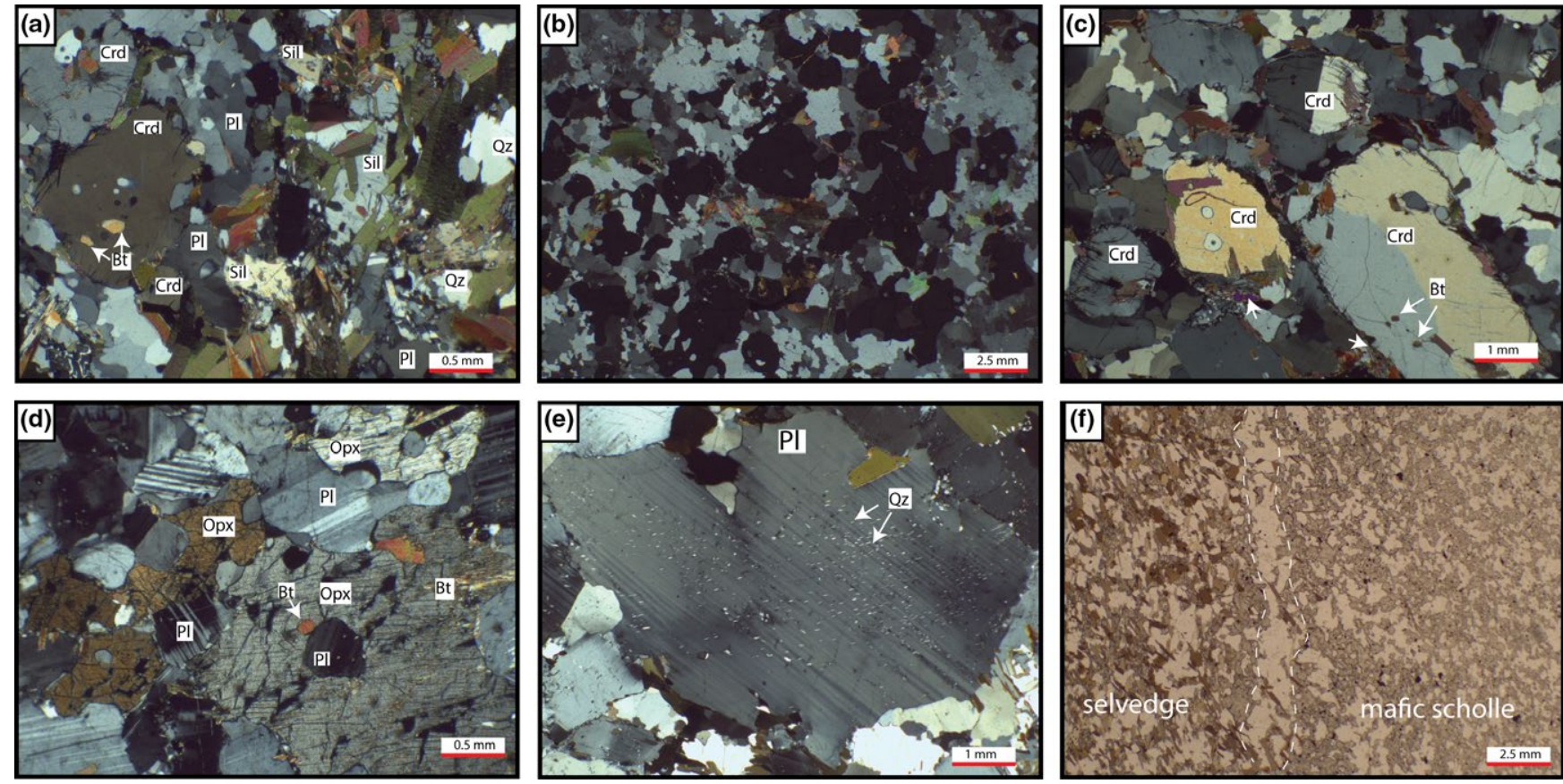

F I G U RE 4 Photomicrographs of metatexite and diatexite. Filled symbols are LK sample series and open symbols are EC series. (a) Metatexite with layer rich in peritectic cordierite (Crd); outcrop 4. Biotite and sillimanite define a weak foliation. (b) Garnet-rich leucosome in metatexite at outcrop 4. Mineral assemblage in the leucosome is plagioclase + quartz + K-feldspar + biotite + garnet + sillimanite. $(c)$ Typical cordierite-rich diatexite at outcrop 1. Mineral assemblage is plagioclase + quartz + K-feldspar + biotite + cordierite + garnet + sillimanite Cordierite in the bottom centre of the photo has some rounded plagioclase, quartz and biotite inclusions in its core; the biotite is red-brown and interpreted as residual. Arrow indicates the rim biotite + sillimanite partly replacing cordierite. (d) Orthopyroxene-bearing diatexite from outcrop 1. Note the small round red-brown biotite inclusions (arrowed) in the orthopyroxene, and absence of biotite in the matrix of this particular diatexite, indicating that this diatexite has passed biotite-out. The mineral assemblage is plagioclase + quartz + K-feldspar + orthopyroxene. (e) Plagioclase with quartz inclusions in diatexite from close to a selvedge. (f) Example of a thin plagioclase band developed subparallel to the selvedge-mafic scholle contact

Point counting indicates that EC23 contains 8.7 modal\% garnet and 5.9 modal\% of cordierite; isopleth lines which correspond to these amounts, g9 (9 modal\% of garnet) and c6 (6 modal\% of cordierite) respectively, are shown on the pseudosection.

The conditions for the contact metamorphism which formed diatexite EC23 are estimated to be 4.8 to $5.8 \mathrm{kbar}$ and 820 to $850^{\circ} \mathrm{C}$, constrained by the following. (a) The mineral assemblage in EC23 lies between c6 and g9 on Figure 8. (b) EC23 lies to the left of the orthopyroxene field as none is present in the sample. (c) Since higher temperature diatexites a few metres closer to the Baie à Cadie dyke do contain orthopyroxene, a pressure above $\mathrm{c} 6$ and the orthopyroxene-in intersection would preclude its formation.

\section{\begin{tabular}{l|l}
8 & MINERAL CHEMISTRY
\end{tabular}}

\section{1 | Plagioclase}

Plagioclase is the only major silicate phase present in the biotite-rich selvedges, adjacent mafic scholle and diatexite; hence, it is the only major mineral for which a compositional profile can be made across the selvedges. Figure 9 shows the change in plagioclase composition along seven profiles from mafic scholle across the selvedge and into the diatexite, representative plagioclase compositions in different parts of a profile are given in Table 4. Three different patterns are evident from the profiles and correspond well to the three selvedge subtypes described above.

The compositional profiles for subtype I selvedges (Figure 9) can be divided into four parts. (a) The portion of the profile near the core of the mafic schollen to $\sim 1 \mathrm{~mm}$ before the start of the selvedge in which the plagioclase changes from $\sim \mathrm{An}_{85}$ to $\sim \mathrm{An}_{77}$, at a rate of $\sim 0.8 \mathrm{An} \% \mathrm{~mm}^{-1}$. (b) A narrow zone $\sim 1 \mathrm{~mm}$ immediately before biotite appears in which there is a significant change in plagioclase composition from $\sim \mathrm{An}_{77}$ to $\sim \mathrm{An}_{55}$; this amounts to $16.1 \mathrm{An} \% \mathrm{~mm}^{-1}$ over that distance. (c) Within the biotite selvedge itself, plagioclase changes in composition from $\sim \mathrm{An}_{55}$ to $\sim \mathrm{An}_{42}$ at an average rate of $\sim 1.2 \mathrm{An} \% \mathrm{~mm}^{-1}$. (d) From the selvedge-diatexite contact to the end of the measured profiles plagioclase becomes progressively more sodic changing from $\mathrm{An}_{42}$ to $\mathrm{An}_{35}$, decreasing at a rate of $\sim 0.9 \mathrm{An} \% \mathrm{~mm}^{-1}$. 

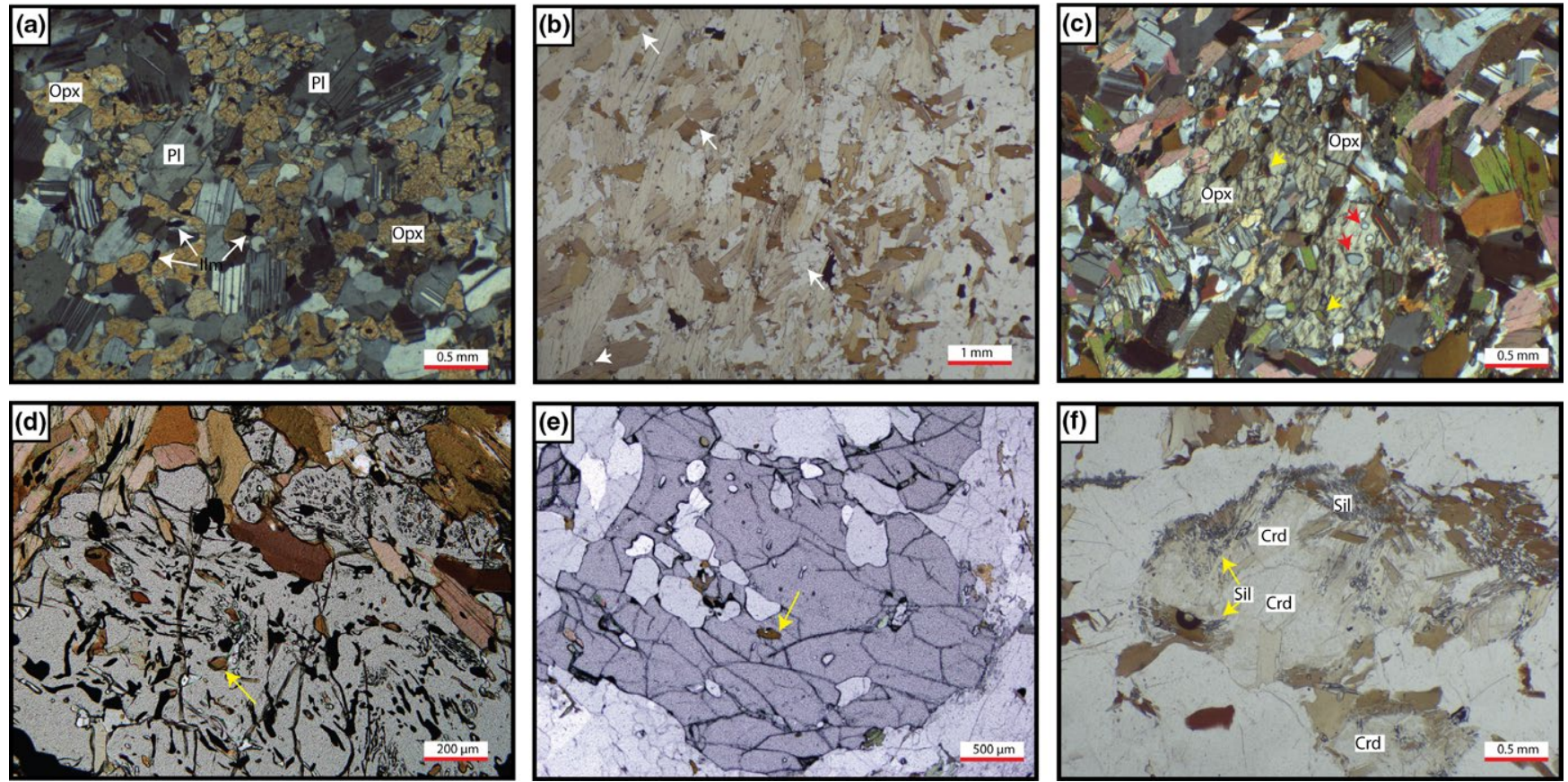

F I G U RE 5 Photomicrographs of microstructures. (a) Mafic scholle distant from the selvedge (EC24A); with mineral assemblage orthopyroxene + plagioclase + ilmenite. Note the small grain size of orthopyroxene. (b) Typical euhedral biotite with high aspect ratio in selvedge (sample LK5A). The biotites delineate a foliation parallel to the contact between selvedge and its adjacent rocks. Note the small rounded apatite (arrowed) and ilmenite grains oriented with the biotite in selvedge. (c) Orthopyroxene in subtype I selvedge (LK4A) with assemblage of orthopyroxene + plagioclase + biotite + quartz + ilmenite. Orthopyroxene forms large porphyroblasts that have inclusions of biotite, plagioclase and quartz, features which differentiate it from the orthopyroxene in the scholle. (d) Typical garnet porphyroblast in selvedge (LK6B) containing inclusions of biotite + plagioclase + ilmenite that occupy $\sim 20$ modal $\%$ of the garnet; $~ 90 \%$ of the inclusions are ilmenite. Note the ilmenite is oriented, and that the biotite inclusions (arrowed) in the core are small rounded, red-brown grains with $\mathrm{TiO}_{2}$ contents up to $5 \mathrm{wt} \%$ that are interpreted to be residual biotite. In contrast, the biotite included, or partially included, in the rims of the garnet is larger and subhedral, typical of the biotite found in the selvedge itself. (e) Garnet porphyroblast with rounded inclusions of residual biotite (arrowed), quartz, plagioclase and ilmenite, LK4B. Note the much lower proportion of inclusions and the virtual absence of ilmenite, features that distinguish it from selvedge garnet. (f) Biotite replacing peritectic cordierite (LK2D). Most biotite is intergrown with sillimanite, which ranges in size up to $0.5 \mathrm{~mm}$. Some of the biotites have crystal faces

The profiles for subtype II selvedges (Figure 9) have three distinct segments. (a) Plagioclase from the interior of the mafic scholle to the edge of the biotite selvedge gradually changes from $\sim \mathrm{An}_{92}$ to $\sim \mathrm{An}_{88}$ at an average rate of $\sim 0.7 \mathrm{An} \%$ $\mathrm{mm}^{-1}$. (b) Across the biotite selvedge, plagioclase changes from $\sim \mathrm{An}_{88}$ to $\sim \mathrm{An}_{60}$ at an increasing rate (i.e. a convex curve); the average rate over this segment is $\sim 3.7 \mathrm{An} \% \mathrm{~mm}^{-1}$. (c) Plagioclase changes from $\sim \mathrm{An}_{60}$ at the selvedge-diatexite transition to $\mathrm{An}_{35}$ at the end of the profile in the diatexite giving an average rate of $1.1 \mathrm{An} \% \mathrm{~mm}^{-1}$.

The compositional profile for a subtype III selvedge (Figure 9) shows the portion in the biotite selvedge and extending into the diatexite to be very similar to a subtype I selvedge. However, the profile is quite different within the mafic scholle; there plagioclase has a much broader segment over which An content decreases (from $\mathrm{An}_{85}$ to $\mathrm{An}_{52}$ ) than in the other selvedge types. The profile shows some scatter in the composition of plagioclase in the mafic scholle. Tracing the profile through the peaks yields a pattern more like subtype I. However, drawing the profile through the troughs results in the extreme pattern which may indicate that the subtype III pattern developed from subtype I in which the compositional changes associated with forming the selvedge have advanced farther into the mafic scholle. If the peaks on the plagioclase composition profile are ignored, then the rate of decrease in the An content in mafic schollen, selvedge and diatexite segments are 3.4 An\% $\mathrm{mm}^{-1}, 1.0 \mathrm{An} \% \mathrm{~mm}^{-1}$ and $0.9 \mathrm{An} \%$ $\mathrm{mm}^{-1}$ respectively.

F I G U RE 6 Variation diagrams for whole-rock composition of metatexite, diatexite, selvedge and mafic scholle. (a) $\mathrm{MgO}_{\mathrm{gs}} \mathrm{SiO}$. (b) $\mathrm{Co}$ vs $\mathrm{SiO}_{2}$. (c) $\mathrm{FeO}$ vs $\mathrm{SiO}_{2}$. (d) $\mathrm{Sc}$ vs $\mathrm{SiO}_{2}$. (e) $\mathrm{K}_{2} \mathrm{O}$ vs $\mathrm{SiO}_{2}$. (f) $\mathrm{Rb}_{\text {vs }} \mathrm{SiO}_{2}$. (g). $\mathrm{Zr}$ vs SiO 2 . (h) Th vs $\mathrm{SiO}_{2}$. The EC series sample series are shown as open symbols and the LK series sample as filled symbols with labels; $\mathrm{m}=$ mafic scholle, $\mathrm{d}=$ diatexite and $\mathrm{s}=$ selvedge. Dashed line indicate trend from residual-rich towards melt-rich diatexite migmatites. Greenfield indicates melt-rich leucocratic diatexites 

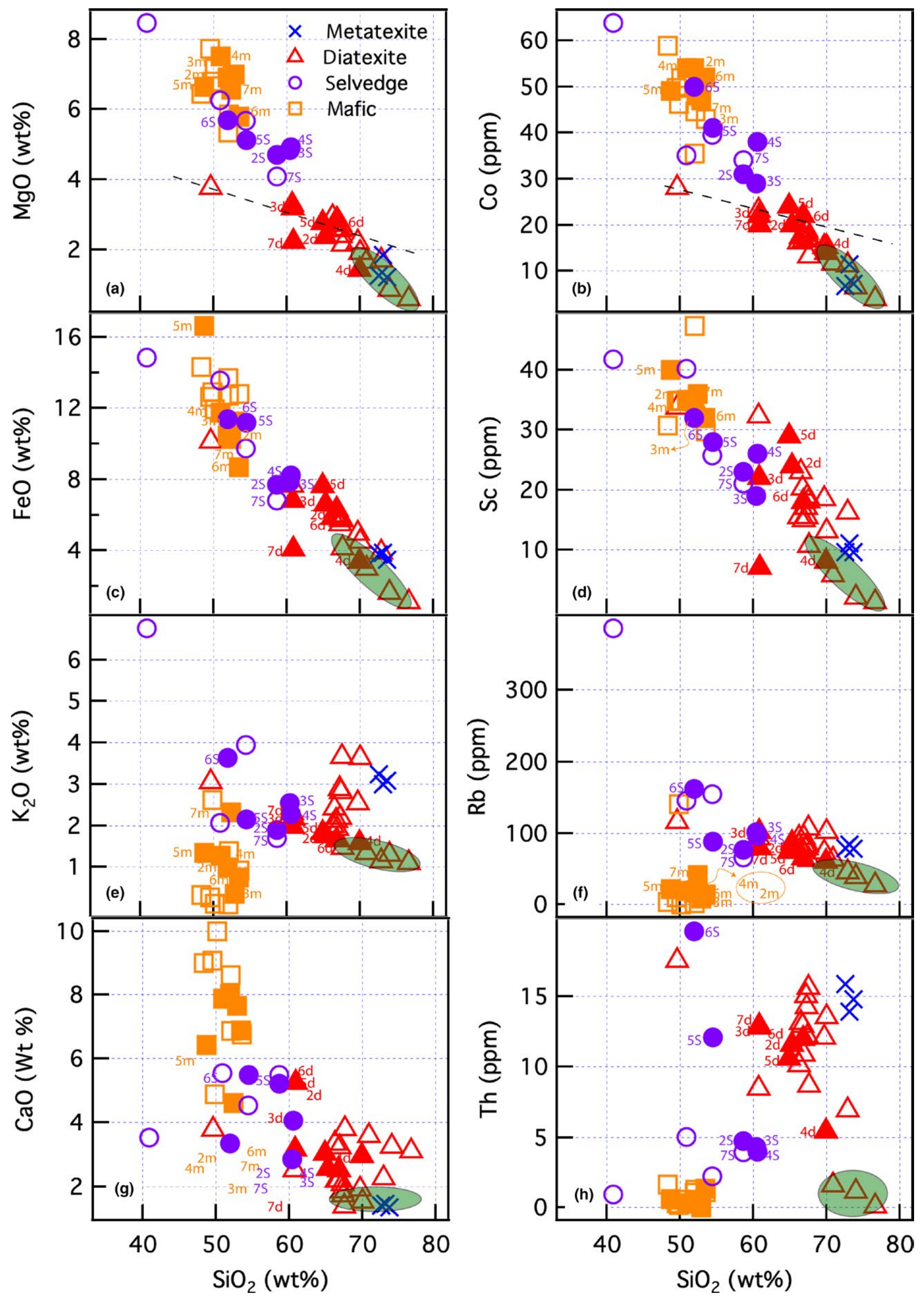

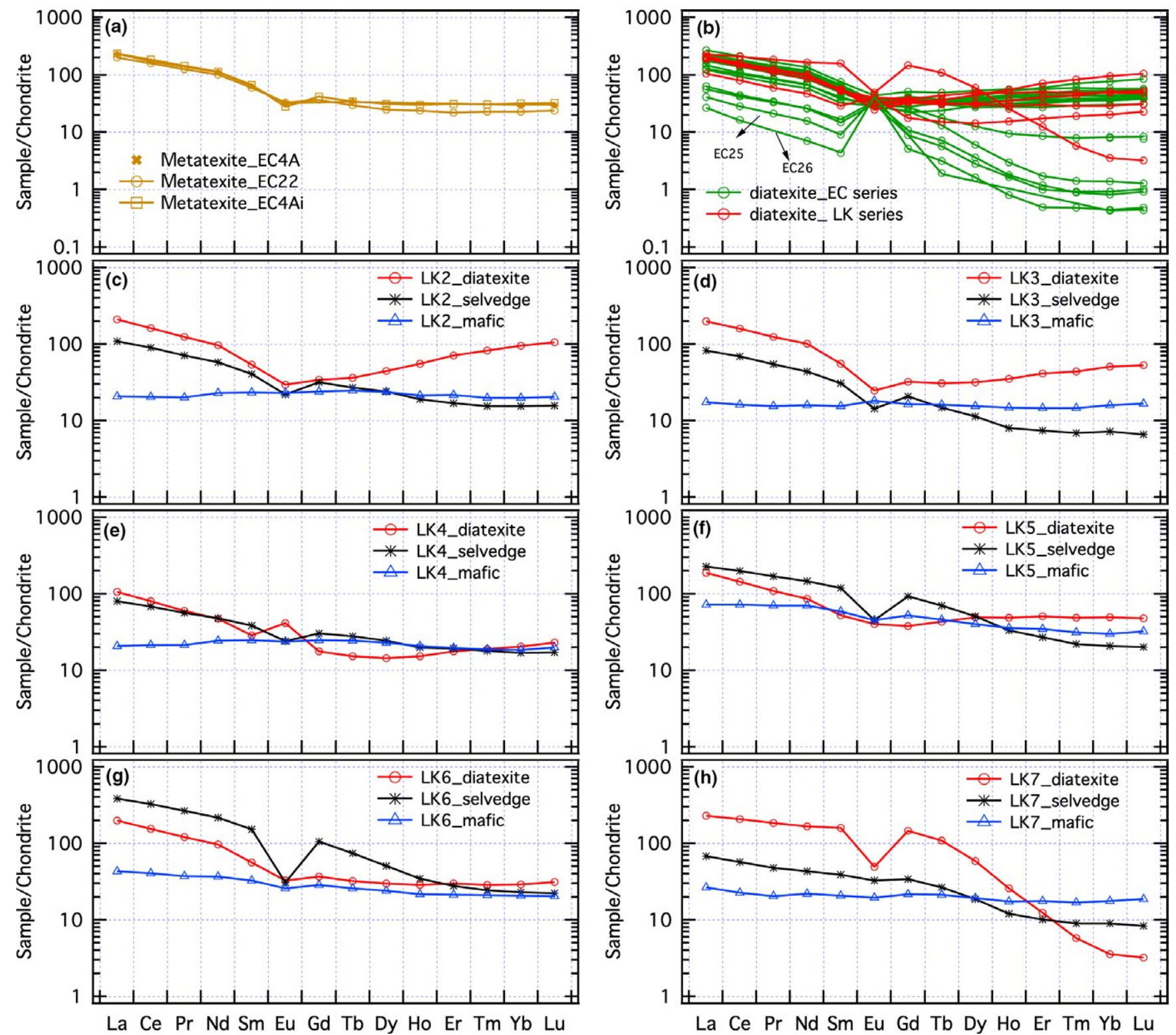

F I G U RE 7 Chondrite normalized rare earth element (REE) patterns for metatexite, diatexite, selvedge and mafic scholle. Dashed lines indicate trend for the diatexite, shaded area outlines diatexite from close to the Baie à Cadie dyke. Note depletion in certain elements (see text for discussion). Normalizing factors are from McDonough \& Sun (1995). (a) Metatexite. (b) LK and EC series diatexites. The remaining plots are for the scholle-selvedge-diatexite triplet sets, (c) LK2, (d) LK3, (e) LK4, (f) LK5, (g) LK6 and (h) LK7

\subsection{Biotite in the selvedges and diatexites}

Biotite occurs in selvedges and diatexites, but not in the mafic schollen. Biotite selected for analysis by EMPA and LA-Q-ICP-MS are from the four types described previously. Whisker box plots from the EMPA data show that selvedge biotite can be differentiated from other types by its high $\mathrm{MgO}$, but lower $\mathrm{Al}_{2} \mathrm{O}_{3}$. Residual biotite is differentiated by its high $\mathrm{TiO}_{2}$ content (Figure 10b). The trace element Sc, V, Cr, Zn and Ga obtained by LA-Q-ICP-MS analysis also provides a basis to discriminate the types of biotite (Figure 10c-e,g). Diatexite biotite and selvedge biotite have similar high Sc and V contents, although diatexite biotite has slightly higher $\mathrm{Cr}, \mathrm{Zn}$ and $\mathrm{Ga}$ contents. However, diatexite

T A B L E 5 Bulk composition of EC23 in mol.\% and normalized to $100 \%$

\begin{tabular}{llllllllll}
$\mathrm{H}_{2} \mathrm{O}$ & $\mathrm{SiO}_{2}$ & $\mathrm{Al}_{2} \mathbf{O}_{3}$ & $\mathrm{CaO}$ & $\mathrm{MgO}$ & $\mathrm{FeO}$ & $\mathbf{K}_{2} \mathrm{O}$ & $\mathrm{Na}_{2} \mathbf{O}$ & $\mathrm{TiO}_{2}$ & $\mathrm{O}^{2}$ \\
3.17 & 70.94 & 9.78 & 2.36 & 4.26 & 4.70 & 1.47 & 2.63 & 0.56 & 0.15 \\
\hline
\end{tabular}


FI G URE $8 \quad P-T$ pseudosection calculated for sample EC23 (locality 1) modelled in NCKFMASHTO system. The peak equilibrium mineral assemblage in EC23 is located in divariant field of garnet + K-feldspar + biotite + cordierite + liquid + plagioclase + quartz + ilmenite. Isopleths for garnet and cordierite content are plotted in this field. Point counting shows the rock to contain 6 modal $\%$ cordierite and 9 modal\% garnet, hence narrowing the $P-T$ conditions for the assemblage to the field outlined by the isopleths $\mathrm{g}_{9}$ and $\mathrm{c}_{6}$, i.e. to between 4.8 and $5.8 \mathrm{kbar}$ and $820-850^{\circ} \mathrm{C}$.

The following mineral abbreviations are used in the figure: pl, plagioclase; q, quartz; ilm, ilmenite; g, garnet; bi, biotite; sill, sillimanite; mu, muscovite; liq, silicate melt; ksp, K-feldspar; opx, orthopyroxene; cd, cordierite

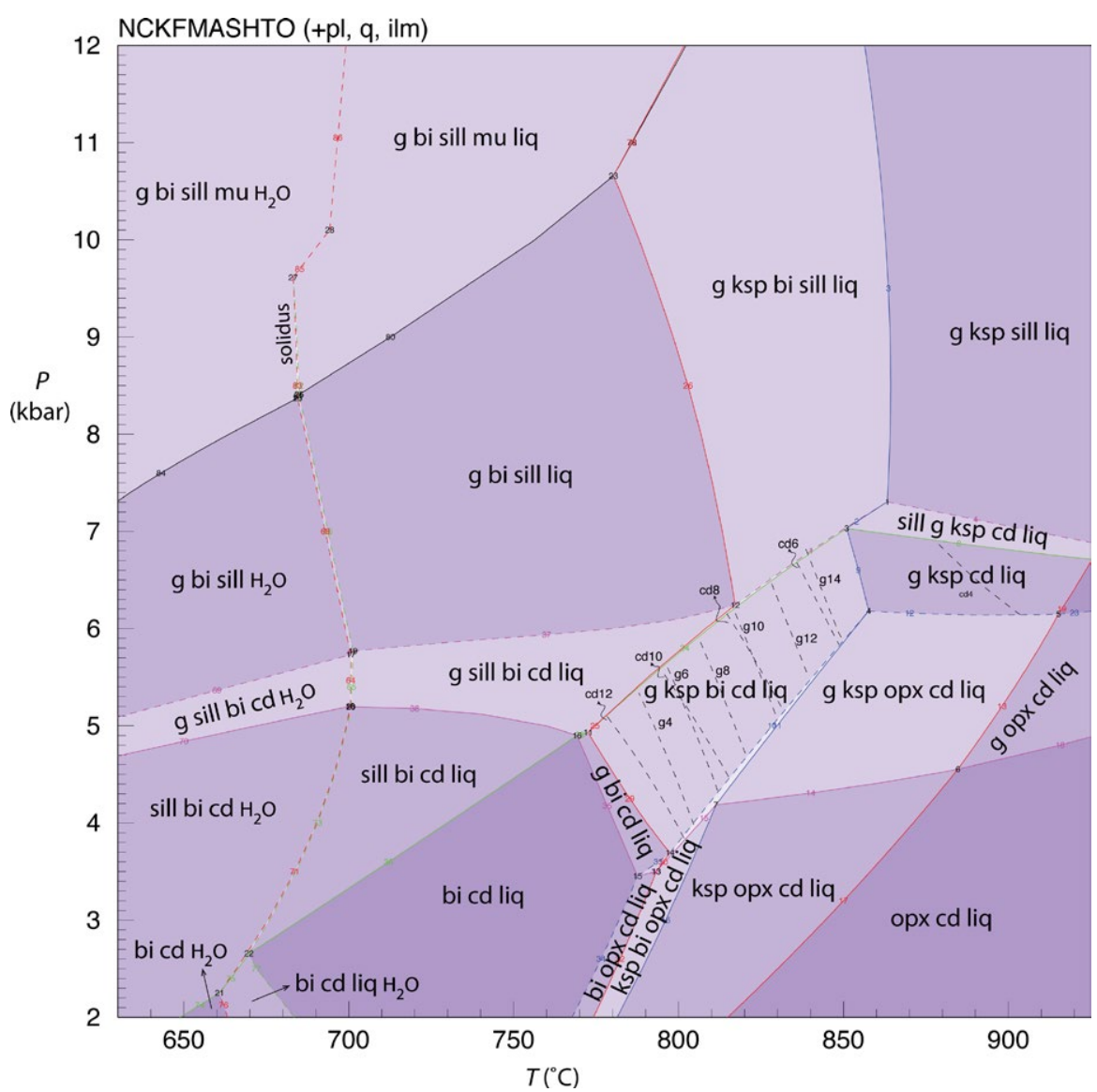

and selvedge biotite differ from both residual and retrograde biotite (Figure 5f) which both have lower Cr, S, Sc and V contents. However, the selvedge biotite is distinguished by a much a wider interquartile range for Sc.

\section{3 | Orthopyroxene in mafic scholle and selvedge}

Orthopyroxene is a major phase in the mafic schollen and occurs in two subtypes of selvedges. The larger, more euhedral orthopyroxene of subtype I selvedges has consistently lower $M g \#(M g \#=100 \times[\mathrm{Mg} /(\mathrm{Mg}+\mathrm{FeO})]$ than orthopyroxene from the associated mafic schollen, $50 \mathrm{vs}$ $\sim 56$ and $49 v s \sim 52$ respectively (Table S2). However, the $\mathrm{Mg \#}$ of orthopyroxene differs from one scholle/selvedge pair to another, which reflects different initial bulk compositions of the mafic rocks. Orthopyroxene in subtype II selvedges plots within the range of $M g \#$ for orthopyroxene (Table S2) from the adjacent mafic scholle (56-57 vs 5457), and so these cannot be distinguished either chemically, or texturally.

\section{4 | Garnet}

The $M g \#$ of garnet from the selvedges and those from the diatexites overlap, and range from 19.4-28.8; selvedge garnet cannot be distinguished from diatexite garnet using $M g \#$. There is no consistent, or significant, variation in $M g \#$ from core to rim within the garnet and they are considered to be unzoned in $\mathrm{Fe}$ or $\mathrm{Mg}$. The grossular content $\left(X_{\mathrm{grs}}\right)$ of garnet from the selvedge and the diatexites overlap and range from 0.03 to 0.079 .

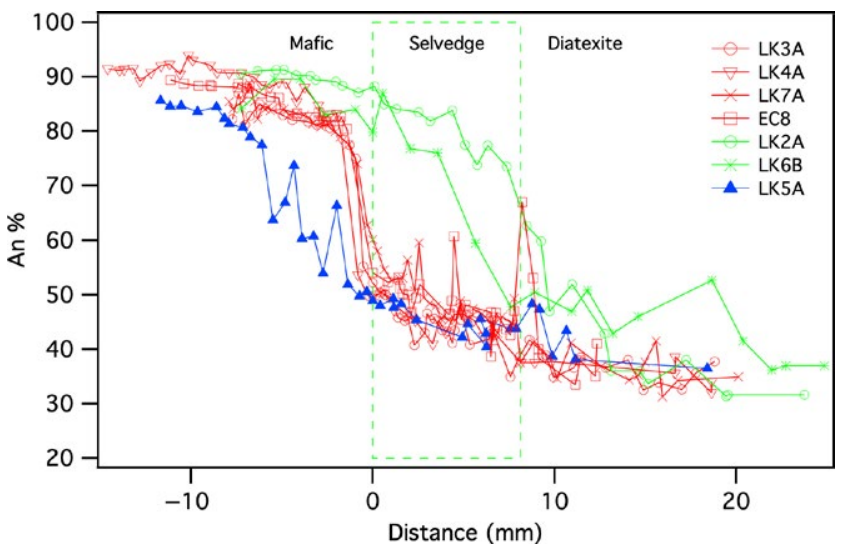

F I G URE 9 Profiles showing the change in plagioclase composition (EMPA data) across the mafic scholle, selvedge and into the diatexite. Selvedge subtypes are colour-coded. Red, subtype I: green, subtype II; blue, subtype III. Note that the region over which plagioclase compositions change is $>4$ times the width of the selvedge 


\section{5 | Amphibole}

Petrographic study shows that the amphibole is orthoamphibole, and according to the calculation routine of Locock (2014) are classified as anthophyllite. The $\mathrm{Mg \#}$ of anthophyllite ranges from $\sim 57$ to $\sim 62$ and is slightly higher than that of the orthopyroxene (50 to 59) they replace.

\section{$9 \mid\left[\mathrm{Al}_{2} \mathrm{O}_{3}\right]-[\mathrm{FeO}]-[\mathrm{MgO}]$ PLOT}

The XRF whole-rock composition of six selvedges and their adjacent mafic schollen and diatexites, together with EMPA compositions of orthoamphibole, orthopyroxene, garnet, cordierite and biotite are shown on a simple AFM triangular plot (Figure 11). Diatexites are more aluminous, but less magnesian than the mafic schollen and the selvedges consistently plot between them in AFM composition space.

Cordierite, garnet, orthopyroxene and anthophyllite have relatively restricted compositional ranges on Figure 11. Partially retrograded cordierite does not show much difference in $M g \#$ from fresh cordierite. The four types of biotite (residual, selvedge, diatexite and retrograde) display significantly wider ranges in composition than the other AFM phases, both in terms of the FM and A components. Residual and diatexite biotite both show a wide range of $\mathrm{Al}$ and $\mathrm{Mg}$, selvedge biotite has a lower Al but higher Mg content in general, whereas retrograde biotite is Al-rich but mostly poorer in Mg. Cordierite falls on the tie-line from aluminosilicate to the most Mg-rich of the retrograde biotite, consistent with the observations that cordierite is replaced by biotite + sillimanite. Biotite also replaces garnet but is more magnesian; hence, a Fe-rich phase must be a product of the garnet-replacing reaction; this is ilmenite.

Orthopyroxene and anthophyllite from the mafic schollen plot close together on Figure 11. Replacement of orthopyroxene by anthophyllite results in a minor increase in $M g \#$ which suggests that a Fe-rich phase was formed as orthopyroxene was replaced; this phase is ilmenite.

\section{0 | BULK ROCK COMPOSITION PROFILES}

Micro-XRF was used to make composition maps of two rock slabs from which profiles (Figure 12a) were constructed from the mafic schollen across the selvedge and into the diatexite. The beam size was $50 \mu \mathrm{m}$ and two different spot separations were used to create the profiles, $60 \mu \mathrm{m}$ for LK2a and $40 \mu \mathrm{m}$ for LK4A. The beam spacing has some effect on resolution; the larger beam spacing gives a smoother profile. Although the beam size and spot separation were constant, grain size was not; therefore, a moving average technique was applied to the data points to smooth out some of the variation due to grain size. Nevertheless, some irregularities remain due to the largest crystals (Figure 12a), but patterns for same elements are very much alike on both profiles.

LA-Q-ICP-MS analyses were used create a compositional profile across sample LK2A (Figure 12b). Eighteen lines of $\sim 5.5 \mathrm{~cm}$ length (4 $\mathrm{mm}$ apart in the selvedge, $8 \mathrm{~mm}$ outside it) were ablated parallel to selvedge in order to reduce the effect of irregular grain size and modal proportions on the traverse. The average for each line was used to make the profile. Profiles for LK2A show that laser ablation (Figure 12b) and micro-XRF (Figure 12a) techniques yield generally similar major element profiles, e.g. for $\mathrm{K}_{2} \mathrm{O}, \mathrm{Na}_{2} \mathrm{O}$ and $\mathrm{CaO}$. The laser ablation results indicate that the ASI (aluminium saturation index) is almost constant across the profile. However, there are some differences; the laser profile shows $\mathrm{Al}_{2} \mathrm{O}_{3}$ to rise in the scholle towards the selvedge, peak in the first third of it, and thereafter decrease in the same manner as the micro-XRF profile.

The whole-rock $\mathrm{Al}_{2} \mathrm{O}_{3}$ and $\mathrm{CaO}$ decrease in step across the selvedge (Figure 12a). Since plagioclase is the host for both components in the mafic scholle, this pattern could reflect decreasing modal abundance of plagioclase, or decreasing anorthite. The increase in $\mathrm{Na}_{2} \mathrm{O}$ is consistent with decreasing anorthite. Both $\mathrm{Al}_{2} \mathrm{O}_{3}$ and $\mathrm{CaO}$ continue to decline together across the selvedge and into the first few millimetres of diatexite. However, $\mathrm{CaO}$ increases slightly over a $10-\mathrm{mm}$ interval farther into the diatexite, whereas $\mathrm{Al}_{2} \mathrm{O}_{3}$ continues to decline. Both $\mathrm{CaO}$ and $\mathrm{Al}_{2} \mathrm{O}_{3}$ show some variability in the diatexite beyond $15 \mathrm{~mm}$ from the selvedge, likely a consequence of greater heterogeneity in grain size in that part of the diatexite.

The $\mathrm{K}_{2} \mathrm{O}$ content in the mafic scholle begins to decrease about $15 \mathrm{~mm}$ from the selvedge, but at about $6 \mathrm{~mm}$ from the selvedge it begins to increase. The maximum $\mathrm{K}_{2} \mathrm{O}$ occurs in the inner third to half of the selvedge, where the modal proportion of biotite is highest, and then declines gradually into the diatexite. The diatexite immediately next to the selvedge is depleted in $\mathrm{K}_{2} \mathrm{O}$, as also shown by the whole-rock composition (Figure 6a-h). Variations in $\mathrm{K}_{2} \mathrm{O}$ in the diatexite begin at the same distance as the variations in $\mathrm{CaO}, \mathrm{Na}_{2} \mathrm{O}$ and $\mathrm{Al}_{2} \mathrm{O}_{3}$. The $\mathrm{MgO}$ is essentially constant in

F I G U RE 10 Differences in the trace element contents (LA-Q-ICP-MS) of the four types of biotite identified in the selvedges and diatexites shown by whisker box plots for $\mathrm{MgO}, \mathrm{TiO}_{2}, \mathrm{~V}, \mathrm{Zn}, \mathrm{Cr}, \mathrm{Ga}, \mathrm{Sc}$ concentrations and counts per second for $\mathrm{S}$, (a) to (f) respectively. Number of grains analysed are residual biotite 81 , selvedge biotite 68 , diatexite biotite 84 and retrograde biotite 46 . Note that diatexite and selvedge biotite are very similar 

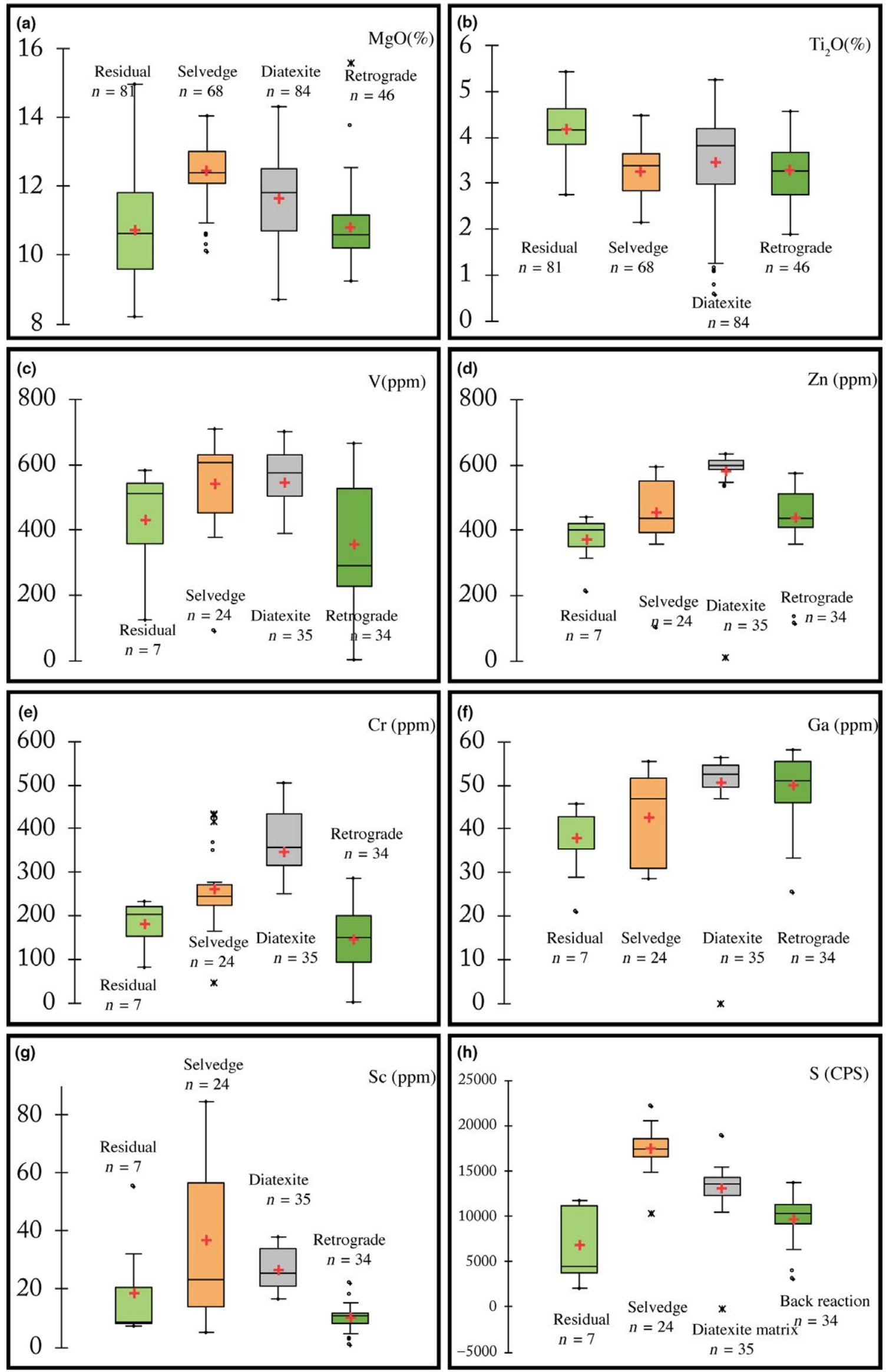


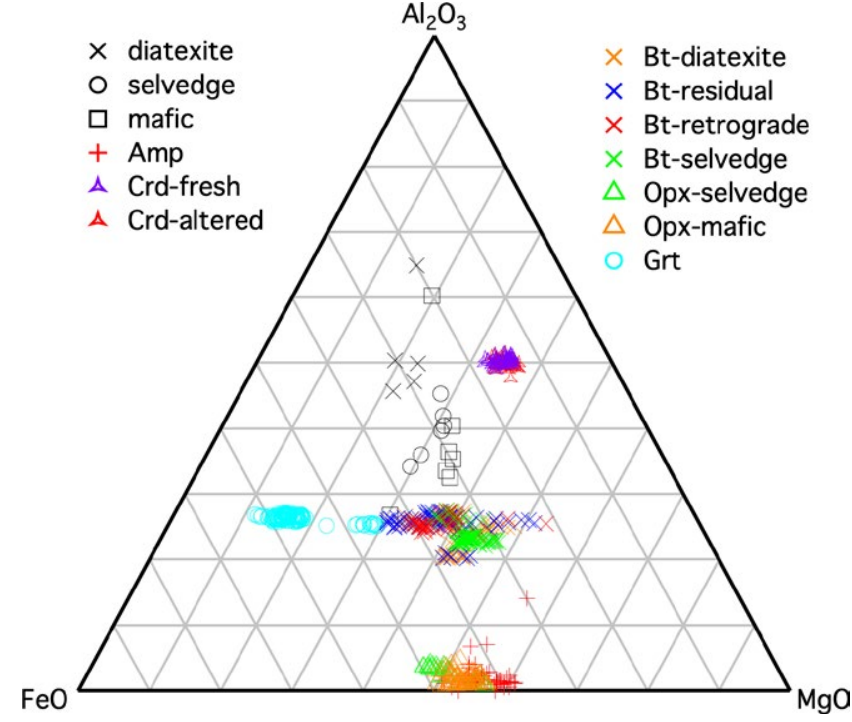

F I G U RE 11 [ $\left.\mathrm{Al}_{2} \mathrm{O}_{3}\right]-[\mathrm{FeO}]-[\mathrm{MgO}]$ plot showing bulk composition of LK series samples, amphibole, biotite, cordierite, garnet and orthopyroxene. Cordierite is subdivided into fresh and altered. Orthopyroxene from mafic and selvedges are separated. Biotite are subdivided into four groups according to microstructure. Number of analyses are amphibole 65 , orthopyroxene from selvedge 26 , orthopyroxene from mafic scholle 56 , garnet 109 , altered cordierite 55 , fresh cordierite 54 , residual biotite 81 , diatexite biotite 84 , selvedge biotite 68 and retrograde biotite 46

the mafic scholle, decreases significantly across the selvedge and just into the diatexite and thereafter declines a little until $\sim 20 \mathrm{~mm}$ into the diatexite, but increases slightly farther out. The $\mathrm{FeO}$ profile differs from $\mathrm{MgO}$ in that it begins to decrease well within the mafic scholle, declines abruptly across the selvedge and first few millimetres of the diatexite, before showing an irregular distribution outwards into the diatexite. The hosts for $\mathrm{FeO}$ in the mafic scholle are orthopyroxene and ilmenite. Since $\mathrm{MgO}$ is constant in the mafic scholle and $\mathrm{Mg \#}$ changes little (Figure 11), the model proportion of pyroxene is probably constant. Thus, the decrease in $\mathrm{FeO}$ points to a decrease in modal ilmenite in outer part of the mafic scholle. Irregularities for $\mathrm{FeO}$ in the diatexite may reflect the presence of garnet porphyroblasts.

Whole-rock trace element profiles from the laser ablation traverses on LK2A show that the trends for $\mathrm{Rb}$ and $\mathrm{Cs}$ are very similar (Figure 13a,b), and closely resemble the $\mathrm{K}_{2} \mathrm{O}$ profile (Figure 12a,b). All these elements are controlled by the distribution of biotite. The profile for $\mathrm{Sr}$ (Figure 13c) in the mafic scholle, selvedge and diatexite resembles that of $\mathrm{CaO}$ rather than $\mathrm{Na}_{2} \mathrm{O}$, but shows more variation farther into the diatexite. Hence, Sr mainly substitutes for $\mathrm{CaO}$ in plagioclase. The profile for B (Figure 13d) is similar to that of $\mathrm{K}_{2} \mathrm{O}$ in the selvedge and diatexite, thus B is likely associated with biotite. The profile for V (Figure 13e) across the selvedge resembles that of $\mathrm{FeO}$, but has a peak within the selvedge; this is consistent with the observed increase in modal ilmenite in the selvedge.

\section{DISCUSSION}

The petrology and geochemistry across the biotite-rich selvedges and adjacent rocks give insights into the chemical exchanges that occurred between the mafic schollen and diatexite migmatite. The first point to consider is what these changes indicate about the source of components required to make biotite, the characteristic mineral of the selvedges. Secondly, using this information to suggest simplified selvedge-forming reactions. Finally, what effect did the presence of selvedges have on the development of the migmatite.

\section{1 | Changes across the selvedges}

There are marked changes in mineral assemblage (Table 2) across the selvedges; an Opx $+\mathrm{Pl}$ metamafite is separated from a $\mathrm{Crd}+\mathrm{Bt}+\mathrm{Grt}+\mathrm{Qz}+\mathrm{Pl}+\mathrm{Kfs}+$ Melt diatexite by a $\mathrm{Bt}+\mathrm{Pl}+\mathrm{Qz}$ selvedge. Therefore, the changes shown by the compositional profiles must be interpreted in terms of which phases are breaking down and which are growing in the selvedge-forming process.
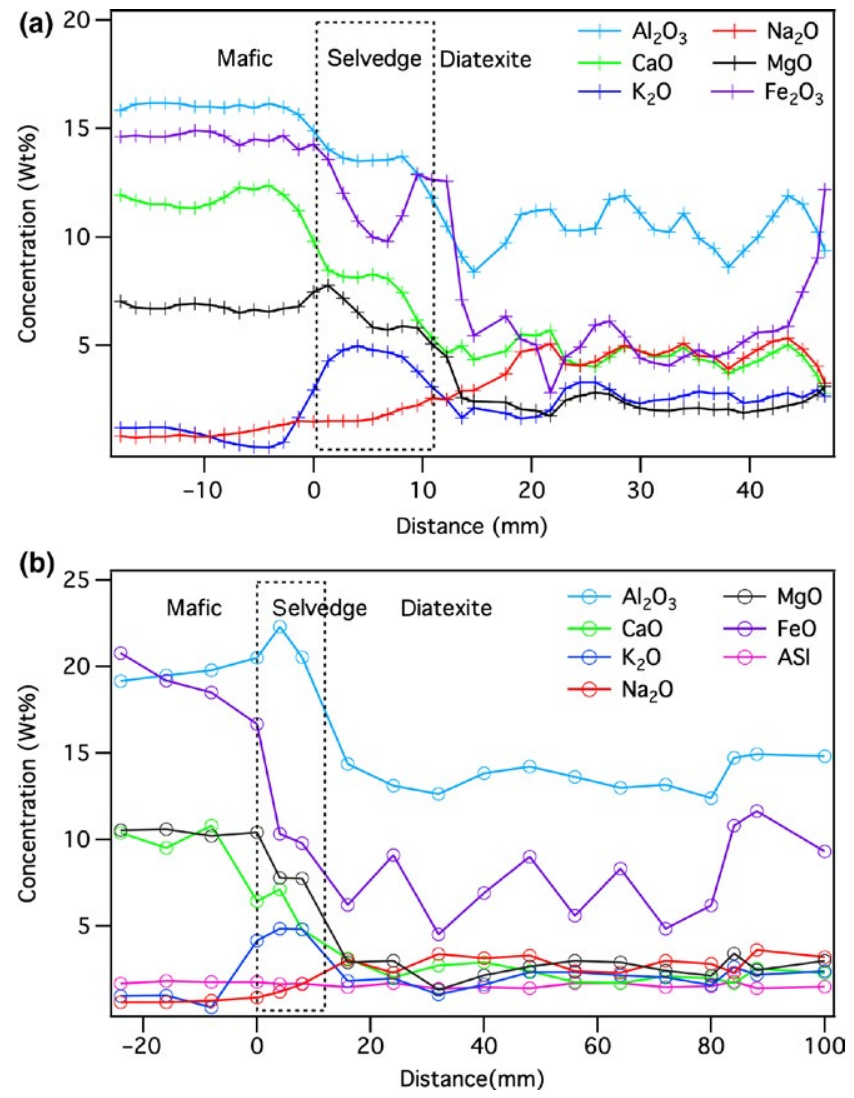

F IG URE 12 Major element whole-rock compositional profiles for the LK2 rock slab, mafic scholle, through selvedge into diatexite from left to right. (a) Profiles made from micro-XRF analyses. (b) Compositional profiles made from LA-Q-ICP-MS analyses. Methods are described in the text. Distances indicate position relative to the mafic-selvedge contact. Note the overall similarity in the profiles made from the two different methods 
Plagioclase is the only major phase present in all three rock types. All profiles (Figure 9) indicate a decrease in anorthite component outwards from the mafic scholle, although there are differences in detail between the subtypes of selvedge. Since the selvedge has the lowest modal abundance of plagioclase (Table 2), this means that $\mathrm{Na}_{2} \mathrm{O}$ has been added to the selvedge and outer scholle, but $\mathrm{CaO}$ has been lost from the scholle and selvedge and gained by the diatexite next to the selvedge.

Biotite is the principal mineral in the selvedges and the whole-rock composition profiles (Figure 12a,b) provide evidence of where the components to form biotite originated. The schollen are anhydrous with essentially no $\mathrm{K}_{2} \mathrm{O}$; therefore, the $\mathrm{H}_{2} \mathrm{O}$ and $\mathrm{K}_{2} \mathrm{O}$ to make the biotite came from the diatexite. The $\mathrm{H}_{2} \mathrm{O}$ came from the melt, whereas $\mathrm{K}_{2} \mathrm{O}$ could have come from either melt, or the peritectic K-feldspar confirmed by the pseudosection modelling. The presence of plagioclase containing inclusions of quartz in diatexites next to the selvedges is consistent with the exchange of $\mathrm{K}$ in the $\mathrm{K}$-feldspar of the diatexite by $\mathrm{Ca}$ from the mafic scholle and $\mathrm{Na}$ from the melt converting it to plagioclase $\left(\mathrm{An}_{49}\right)+$ quartz. The released potassium goes to form biotite in the selvedge. This replacement of $\mathrm{K}$-feldspar is by a reaction such as:

$$
\begin{aligned}
& 87 \mathrm{KAlSi}_{3} \mathrm{O}_{8}+13 \mathrm{NaAlSi}_{3} \mathrm{O}_{8}+33 \mathrm{Ca}^{2+}+21 \mathrm{Na}^{+} \\
& =33 \mathrm{CaAl}_{2} \mathrm{Si}_{2} \mathrm{O}_{8}+34 \mathrm{NaAlSi}_{3} \mathrm{O}_{8}+87 \mathrm{~K}^{+}+132 \mathrm{SiO}_{2}
\end{aligned}
$$

The selvedges have $\mathrm{MgO}, \mathrm{FeO}, \mathrm{CaO}$ and $\mathrm{Al}_{2} \mathrm{O}_{3}$ intermediate between diatexite and scholle indicating the mafic scholle contributed them. A typical mafic scholle has $\sim 45$ modal $\%$ orthopyroxene, the reservoir for ferromagnesian components $\mathrm{MgO}, \mathrm{FeO}, \mathrm{Co}, \mathrm{Cr}, \mathrm{V}$ and Sc. Breakdown of orthopyroxene in the selvedge-forming reaction releases these components which are compatible with biotite (Figure 10).

The selvedges are enriched in $\mathrm{Rb}$ and $\mathrm{Cs}$ relative to the mafic schollen (Figure 13a,b). Bea (1994) showed that K-feldspar is relatively rich in $\mathrm{Rb}$ (100-1,000 ppm), but has low Cs (1-10 ppm) content. Both $\mathrm{Rb}$ and $\mathrm{Cs}$ could have come from the $\mathrm{K}$-feldspar in the diatexite, released upon conversion to plagioclase. However, both could also have come from the anatectic melt in the diatexite into which they partitioned as biotite broke down in meltforming reactions (Figure 8). The redistribution of components as selvedges formed is summarized in Figure 14.

\section{2 | Selvedge-forming reactions}

Each of the three subtypes of selvedge is considered to have formed by variants of a basic reaction between mafic scholle and diatexite. The key elements of such a reaction are that melt and K-feldspar in the diatexite and orthopyroxene and calcic plagioclase in the scholle are reactants as discussed in the previous section. Biotite and the more sodic plagioclase in the selvedges are products of the selvedge-forming reaction. Mafic scholle are quartz-free, and quartz first appears at the scholle-selvedge contact and increases in modal amount towards selvedge-diatexite contact; hence, it is likely a product phase also, e.g. from R1.

Since orthopyroxene in subtype I Bt+Pl+Qz+Opx+Ilm selvedges is larger, has crystal faces and a lower $M g \#$
F I G U RE 13 Trace element (LAQ-ICP-MS) whole-rock compositional profiles of LK2 rock slab across mafic scholle, through selvedge into diatexite. The rectangle indicates the selvedge zone; the mafic scholle is to the left and the diatexite to the right. (a) Rb, (b) Cs, (c) Sr, (d) B and (e) $\mathrm{V}$

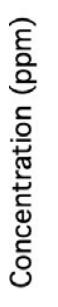

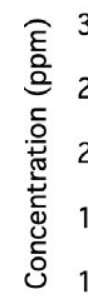

$$
\text { 흘 }
$$

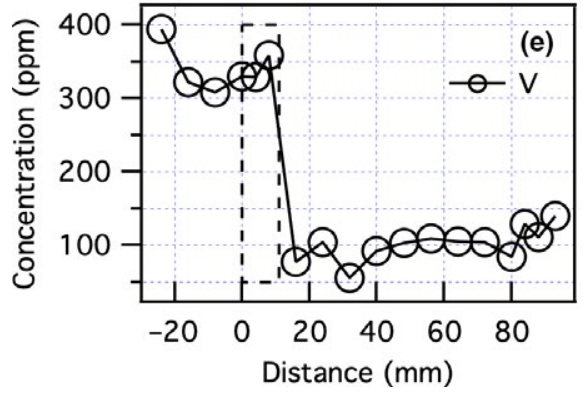

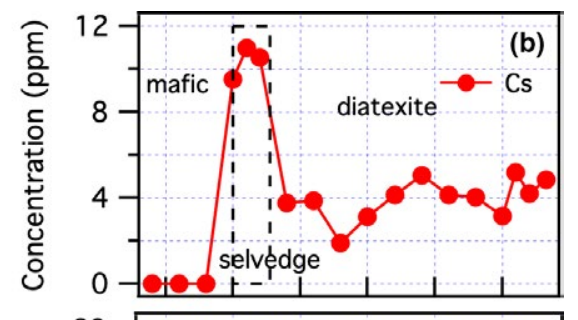

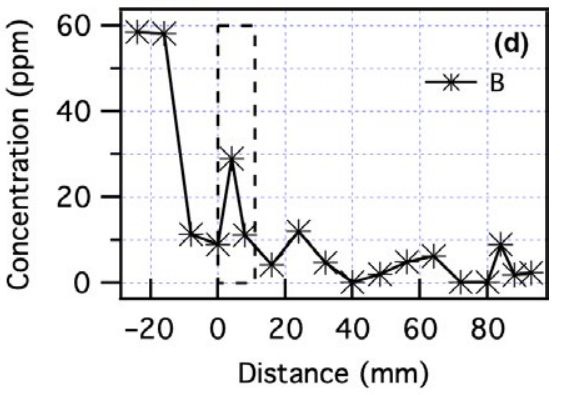


compared to orthopyroxene in the mafic scholle, it is a product phase. Furthermore, since the Mg\# of the scholle orthopyroxene is between that of the selvedge biotite and selvedge orthopyroxene (Figure 11), it is possible the reaction did not produce ilmenite. However, there is a slight variation in modal ilmenite from mafic scholle to selvedge which may indicate ilmenite is a minor product phase (Table. 2). Hence, a simplified reaction for forming these subtype I selvedges is;

$\mathrm{Opx}^{1}+\mathrm{Pl}^{1}+\mathrm{Melt} \pm \mathrm{Ilm}^{1}=\mathrm{Bt}+\mathrm{Pl}^{2}+\mathrm{Qz}+\mathrm{Opx}^{2} \pm \mathrm{Ilm}^{2}$

Subtype II selvedges contain relict orthopyroxene from the mafic schollen, but do not contain the large orthopyroxene crystals like subtype I selvedges; they have garnet instead. This type of selvedge forms around mafic scholle with the highest $\mathrm{Al}_{2} \mathrm{O}_{3}$ content, thus garnet is stabilized instead of orthopyroxene as in subtype I. The simplified subtype II selvedge-forming reaction is

$$
\mathrm{Opx}^{1}+\mathrm{Pl}^{1}+\mathrm{Melt} \pm \mathrm{Ilm}^{1}=\mathrm{Bt}+\mathrm{Pl}^{2}+\mathrm{Qz}+\mathrm{Grt} \pm \mathrm{Ilm}^{2}
$$

Subtype III selvedges have neither orthopyroxene, nor garnet as a product phase. Rather, ilmenite and apatite are believed to be product phases based on the modal analyses (Table 2). The biotite in subtype III selvedges has a higher $M g \#$ than the associated scholle orthopyroxene. Consequently, when the orthopyroxene breaks down to make biotite an Fe-rich product phase, such as ilmenite is anticipated. Hence, the simplified selvedge III-producing reaction is

$\mathrm{Opx}^{1}+\mathrm{Pl}^{1}+\mathrm{Melt}+\mathrm{Ilm}^{1}=\mathrm{Bt}+\mathrm{Pl}^{2}+\mathrm{Qz}+\mathrm{Ilm}^{2}+\mathrm{Ap}$

Mafic scholle from LK5A has the highest $\mathrm{P}_{2} \mathrm{O}_{5}$ (see Table 3) and the selvedge around it has the highest modal apatite. In contrast, modal apatite is not high in the selvedge adjacent to a diatexite with very similar, high $\mathrm{P}_{2} \mathrm{O}_{5}$ content (LK7A). High apatite abundance in a selvedge appears to be primarily controlled by the $\mathrm{P}_{2} \mathrm{O}_{5}$ content in the mafic scholle, not the diatexite.

The modal data (Table 2) show the decrease in orthopyroxene from mafic scholle into the subtype I and II selvedges is matched by an increase in the modal proportions of biotite, quartz and garnet in the selvedge. As more orthopyroxene breaks down, the more biotite, quartz and garnet are produced. This provides a means to compare of the degree of completeness of the selvedge-forming reaction. For subtype I selvedges, LK4A presents the most complete selvedge-producing reaction and LK3A the least. For subtype II selvedges, LK2A preserves an earlier stage of the reaction, whereas LK6A represents a more advanced stage.

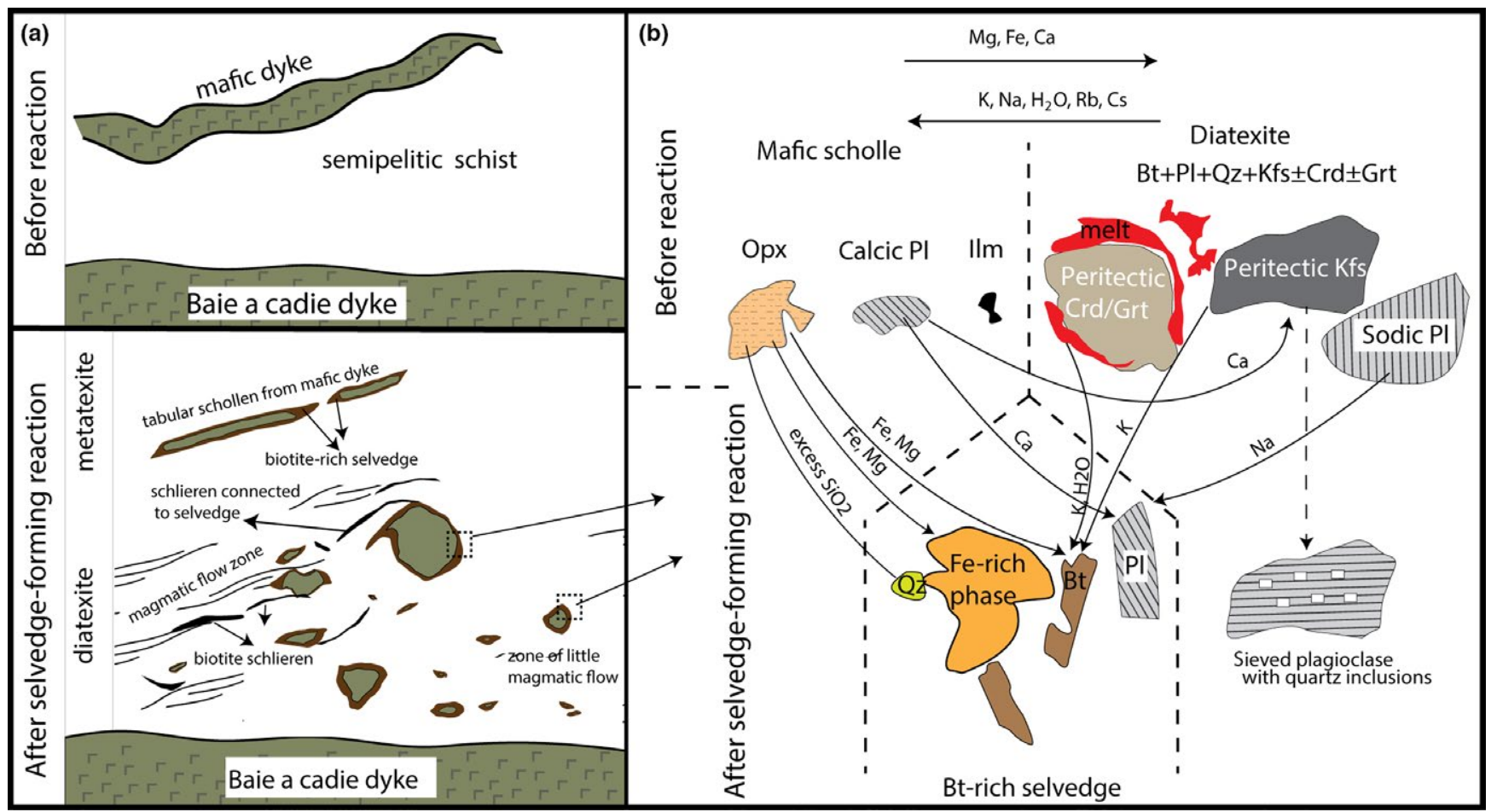

F I G U RE 14 Schematic model for the formation of the biotite-rich selvedges at Lac Kenogami. (a) Left upper panel: Initial outcrop relationship between the Saguenay Gneiss Complex and its mafic dykes and the younger Baie à Cadie dyke. Left lower panel: Stage after partial melting with anatectic melt-present, showing the biotite-rich selvedges between mafic scholle and the migmatite immediately surrounding it compared to the case where strong magmatic flow in the diatexite erodes selvedges and creates schlieren. (b) Right; simplified selvedge-forming reaction mechanism between mafic scholle and surrounding diatexite. The mafic scholle contributes $\mathrm{Mg}, \mathrm{Fe}$ and $\mathrm{Ca}$, whereas the diatexite contributed $\mathrm{K}, \mathrm{Na}, \mathrm{H}_{2} \mathrm{O}, \mathrm{Rb}$, Cs to the biotite selvedge 


\section{3 | Recycling of mafic selvedges in the diatexite}

The reaction between diatexite and mafic scholle produced biotite selvedges and that represent $5.9 \%$ of the outcrop area of the Lac Kenogami migmatite. Apart from the $\sim 6 \mathrm{~cm}$ wide depletion halo in the diatexite immediately around the schollen, what other effects does the formation of selvedges have? Outcrop evidence shows that schollen in regions where the diatexite has the strongest flow fabric are asymmetric with thinner selvedges on the long side (Figure 3b). Moreover, biotite schlieren in the diatexite connect to biotite selvedges, and so appear to originate by erosion of the selvedges. This process returns biotite back into the diatexite. Can this biotite be traced?

Diatexites distant from the selvedges contain between $\sim 6$ and $\sim 30 \%$ biotite (Table 1); the average is $\sim 16.3 \%$. The pseudosection modelling (Figure 8) shows that at temperatures $>850^{\circ} \mathrm{C}$, the Lac Kenogami migmatites cross orthopyroxene-in and become biotite-absent. Such migmatites occur closest to the Baie à Cadie dyke. However, some of these contain a few per cent biotite; some occurs as inclusions of residual biotite and as retrograde replacement of peritectic phases, the remaining few per cent of biotite is in the matrix. Some, lower temperature diatexites have more biotite than anticipated, the majority of which is matrix biotite, and compositionally distinct from the retrograde and residual biotite (Figure 10a-h). This matrix biotite is, however, very similar to selvedge biotite, particularly in $\mathrm{V}, \mathrm{Cr}$ and $\mathrm{Co}$, trace elements that are highest in the mafic scholle. This is consistent with biotite in the matrix of the diatexite being derived from erosion of the selvedges. This also means that the composition of the diatexite has been modified twice. First by the loss of components such as $\mathrm{K}_{2} \mathrm{O}$, $\mathrm{Na}_{2} \mathrm{O} \mathrm{H}_{2} \mathrm{O}, \mathrm{Rb}$ and $\mathrm{Cs}$ and gain of $\mathrm{CaO}$ in the reaction with mafic scholle to make the selvedges, then later by return of some of these components, plus components, such as $\mathrm{MgO}$, Co and $\mathrm{Cr}$, from the mafic scholle as the biotite is eroded off the selvedge incorporated into the diatexite. Consequently, modal biotite content in the diatexite is not just a function of how far biotite-consuming, melt-producing reactions and peritectic phase-consuming retrograde reactions have advanced, but also how effectively magmatic erosion of reaction selvedges returns biotite. The reaction selvedges are biotite factories and sequester $\mathrm{K}_{2} \mathrm{O}$ and $\mathrm{H}_{2} \mathrm{O}$. In a crustal melting context, erosion of reaction selvedges can be added to the growing list of processes that increase the maficity (Carvalho et al., 2017; Clemens, Stevens, \& Farina, 2011) of felsic magmas.

\section{$12 \mid$ CONCLUSIONS}

This study documents the field characteristics, microstructure, mineral assemblage and geochemistry of biotite-rich selvedges formed between mafic scholle and semipelitic diatexite migmatite. Profiles showing changes in major and trace element composition across the selvedge indicate the selvedge-forming process is the chemical exchange of components $\mathrm{MgO}, \mathrm{FeO}, \mathrm{Al}_{2} \mathrm{O}_{3}$ and associated trace elements such as $\mathrm{Co}, \mathrm{Cr}, \mathrm{Ni}$ and $\mathrm{V}$ into the selvedge zone from mafic scholle and components such as $\mathrm{K}_{2} \mathrm{O}, \mathrm{Na}_{2} \mathrm{O}, \mathrm{H}_{2} \mathrm{O}$, and trace elements $\mathrm{Rb}$ and $\mathrm{Cs}$ from the melt-rich diatexite migmatite into the selvedge zone. Although $\mathrm{H}_{2} \mathrm{O}$ came from the melt in the diatexite, $\mathrm{K}_{2} \mathrm{O}$ and $\mathrm{Na}_{2} \mathrm{O}$ may also have come from peritectic $\mathrm{K}$-feldspar. The diatexite gained $\mathrm{CaO}$ from the mafic scholle. Although the visible biotite selvedge is $\sim 10 \mathrm{~mm}$ wide, the overall width of the reaction zone between the mafic scholle and diatexite is much larger, at least $60 \mathrm{~mm}$.

Once formed the biotite reaction selvedges are recycled back into the host diatexite where magmatic erosion occurs. This return process increases the modal proportion of biotite in the diatexite. The selvedges described in this study are reaction selvedges between dissimilar rocks, one being a melt-bearing diatexite; they are not residuum.

\section{ACKNOWLEDGEMENTS}

This article is part of the first author's PhD research. Lin acknowledges support from the China scholarship council ([2013]7014) and the award from the Merit Scholarship Program for Foreign Students (179332) of the Fonds de Recherche Nature et Technologies (Québec). This research was funded by a Natural Sciences and Engineering Research Council of Canada Discovery Grant (03694-2015) to Sawyer. We thank the journal reviewers R Moraes and M Schwindinger for their constructive reviews and suggestions which helped improve the clarity of the text and several of the figures. We also thank D Robinson for his editorial handling and guidance.

\section{ORCID}

Lina Lin (D) https://orcid.org/0000-0002-8263-823X

\section{REFERENCES}

Acosta-Vigil, A., \& London, D. (2006). Experiments on the kinetics of partial melting of a leucogranite at $200 \mathrm{MPa}_{2} \mathrm{O}$ and $690-800^{\circ} \mathrm{C}$ : Compositional variability of melts during the onset of $\mathrm{H}_{2} \mathrm{O}$-saturated crustal anatexis. Contributions to Mineralogy and Petrology, 151(5), 539-557. https://doi.org/10.1007/s00410-006-0081-8

Ashworth, J. R. (1976). Petrogenesis of migmatites in the Huntly-Portsoy area, north-east Scotland. Mineralogical Magazine, 40(315), 661682. https://doi.org/10.1180/minmag.1976.040.315.01 
Barraud, J., Gardien, V., Allemand, P., \& Grandjean, P. (2004). Analogue models of melt-flow networks in folding migmatites. Journal of Structural Geology, 26(2), 307-324. https://doi.org/10.1016/j. jsg.2003.06.002

Bea, F., Pereira, M. D., \& Stroh, A. (1994). Mineral/leucosome traceelement partitioning in a peraluminous migmatite (a laser ablationICP-MS study). Chemical Geology, 117(1-4), 291-312. https://doi. org/10.1016/0009-2541(94)90133-3

Carvalho, B. B., Sawyer, E. W., \& Janasi, V. A. (2016). Crustal reworking in a shear zone: Transformation of metagranite to migmatite. Journal of Metamorphic Geology, 34(3), 237-264. https://doi. org/10.1111/jmg. 12180

Carvalho, B. B., Sawyer, E. W., \& Janasi, V. A. (2017). Enhancing maficity of granitic magma during anatexis: Entrainment of infertile mafic lithologies. Journal of Petrology, 58(7), 1333-1362. https:// doi.org/10.1093/petrology/egx056

Cenki, B., Kriegsman, L. M., \& Braun, I. (2002). Melt-producing and melt-consuming reactions in the Achankovil cordierite gneisses, South India. Journal of Metamorphic Geology, 20(6), 543-561. https://doi.org/10.1046/j.1525-1314.2002.00388.x

Clemens, J. D., Stevens, G., \& Farina, F. (2011). The enigmatic sources of I-type granites: The peritectic connexion. Lithos, 126(3-4), 174181. https://doi.org/10.1016/j.lithos.2011.07.004

Conrad, W. K., Nicholls, I. A., \& Wall, V. J. (1988). Water-saturated and -undersaturated melting of metaluminous and peraluminous crustal compositions at $10 \mathrm{~kb}$ : Evidence for the origin of silicic magmas in the Taupo Volcanic Zone, New Zealand, and other occurrences. Journal of Petrology, 29(4), 765-803. https://doi.org/10.1093/ petrology/29.4.765

Diener, J. F. A., White, R. W., \& Hudson, T. J. M. (2014). Melt production, redistribution and accumulation in mid-crustal source rocks, with implications for crustal-scale melt transfer. Lithos, 200, 212225. https://doi.org/10.1016/j.lithos.2014.04.021

Genier, F., Bussy, F., Epard, J. L., \& Baumgartner, L. (2008). Waterassisted migmatization of metagraywackes in a Variscan shear zone, Aiguilles-Rouges Massif, western Alps. Lithos, 102(3-4), 575-597. https://doi.org/10.1016/j.lithos.2007.07.024

Hall, D., \& Kisters, A. (2016). Episodic granite accumulation and extraction from the mid-crust. Journal of Metamorphic Geology, 34(5), 483-500. https://doi.org/10.1111/jmg.12190

Hébert, C., Breemen, O., \& Cadieux, A.-M. (2009). Région du réservoir Pipmuascan (SNRC 22E): Synthèse géologique et carte à 1 : 250 000. Ministère des Ressources Naturelles et de la Faune, Gouvernement du Québec, RG 2009-01.

Hébert, C., Cadieux, A.-M., \& Breemen, O. V. (2005). Temporal evolution and nature of Ti-Fe-P mineralization in the anorthositemangerite-charnockite-granite (AMCG) suites of the south-central Grenville Province, Saguenay—Lac St. Jean area, Quebec, Canada. Canadian Journal of Earth Sciences, 42(10), 1865-1880. https:// doi.org/10.1139/e05-050

Hier-Majumder, S., Ricard, Y., \& Bercovici, D. (2006). Role of grain boundaries in magma migration and storage. Earth and Planetary Science Letters, 248(3-4), 735-749. https://doi.org/10.1016/j. eps1.2006.06.015

Hinchey, A. M., \& Carr, S. D. (2006). The S-type Ladybird leucogranite suite of southeastern British Columbia: Geochemical and isotopic evidence for a genetic link with migmatite formation in the North American basement gneisses of the Monashee complex. Lithos, 90(3-4), 223-248. https://doi.org/10.1016/j. lithos.2006.03.003
Holland, T., \& Powell, R. (2011). An improved and extended internally consistent thermodynamic dataset for phases of petrological interest, involving a new equation of state for solids. Journal of Metamorphic Geology, 29(3), 333-383. https://doi. org/10.1111/j.1525-1314.2010.00923.x

Holness, M. B., \& Watt, G. R. (2002). The aureole of the Traigh Bhàn na Sgúrra sill Isle of Mull: Reaction-driven micro-cracking during pyrometamorphism. Journal of Petrology, 43, 511-534. https://doi. org/10.1093/petrology/43.3.511

Johannes, W., Ehlers, C., Kriegsman, L. M., \& Mengel, K. (2003). The link between migmatites and S-type granites in the Turku area, southern Finland. Lithos, 68(3-4), 69-90. https://doi.org/10.1016/ S0024-4937(03)00032-X

Johannes, W., Holtz, F., \& Möller, P. (1995). REE distribution in some layered migmatites: Constraints on their petrogenesis. Lithos, 35(34), 139-152. https://doi.org/10.1016/0024-4937(95)00003-X

Johnson, T. E., \& Brown, M. (2004). Quantitative constraints on metamorphism in the Variscides of southern Brittany-A complementary pseudosection approach. Journal of Petrology, 45(6), 12371259. https://doi.org/10.1093/petrology/egh012

Johnson, T. E., Fisher, S., White, R. W., Brown, M., \& Rollinson, H. R. (2012). Archaean intracrustal differentiation from partial melting of metagabbro-Field and geochemical evidence from the central region of the Lewisian Complex, NW Scotland. Journal of Petrology, 53(10), 2115-2138. https://doi.org/10.1093/petrology/ egs046

Johnson, T. E., Hudson, N. F. C., \& Droop, G. T. R. (2001). Melt segregation structures within the Inzie Head gneisses of the northeastern Dalradian. Scottish Journal of Geology, 37(2), 59-72. https://doi. org/10.1144/sjg37020059

Jones, K. A., \& Brown, M. (1990). High-temperature 'clockwise' P-T paths and melting in the development of regional migmatites: An example from southern Brittany, France. Journal of Metamorphic Geology, 8(3), 551-578. https://doi.org/10.1111/j.1525-1314.1990. tb00486.x

Kohlstedt, D. L., King, D. S., \& Holtzman, B. K. (2010). Stress-driven melt segregation in deforming partially molten rocks. AGU Fall Meeting Abstracts.

Kriegsman, L. M. (2001). Partial melting, partial melt extraction and partial back reaction in anatectic migmatites. Lithos, 56(1), 75-96. https://doi.org/10.1016/s0024-4937(00),00060-8

Lavaure, S., \& Sawyer, E. W. (2011). Source of biotite in the Wuluma Pluton: Replacement of ferromagnesian phases and disaggregation of enclaves and schlieren. Lithos, 125(1-2), 757-780. https://doi. org/10.1016/j.lithos.2011.04.005

Locock, A. J. (2014). An Excel spreadsheet to classify chemical analyses of amphiboles following the IMA 2012 recommendations. Computers \& Geosciences, 62, 1-11. https://doi.org/10.1016/j. cageo.2013.09.011

McDonough, W. F., \& Sun, S. S. (1995). The composition of the Earth. Chemical geology, 120(3-4), 223-253. https://doi. org/10.1016/0009-2541(94)00140-4

Morfin, S., Sawyer, E. W., \& Bandyayera, D. (2013). Large volumes of anatectic melt retained in granulite facies migmatites: An injection complex in northern Quebec. Lithos, 168-169, 200-218. https://doi. org/10.1016/j.lithos.2013.02.007

Morfin, S., Sawyer, E. W., \& Bandyayera, D. (2014). The geochemical signature of a felsic injection complex in the continental crust: Opinaca Subprovince, Quebec. Lithos, 196-197, 339-355. https:// doi.org/10.1016/j.lithos.2014.03.004 
Obata, M., Yoshimura, Y., Nagakawa, K., Odawara, S., \& Osanai, Y. (1994). Crustal anatexis and melt migrations in the Higo metamorphic terrane, west-central Kyushu, Kumamoto, Japan. Lithos, 32(12), 135-147. https://doi.org/10.1016/0024-4937(94),90026-4

Otamendi, J. E., \& Patino Douce, A. E. (2001). Partial melting of aluminous metagreywackes in the northern Sierra de Comechingones, Central Argentina. Journal of Petrology, 42(9), 1751-1772. https:// doi.org/10.1093/petrology/42.9.1751

Palin, R. M., White, R. W., \& Green, E. C. R. (2016). Partial melting of metabasic rocks and the generation of tonalitic-trondhjemiticgranodioritic (TTG) crust in the Archaean: Constraints from phase equilibrium modelling. Precambrian Research, 287, 73-90. https:// doi.org/10.1016/j.precamres.2016.11.001

Patino Douce, A. E., \& Beard, J. S. (1995). Dehydration-melting of biotite gneiss and quartz amphibolite from 3 to $15 \mathrm{kbar}$. Journal of Petrology, 36(3), 707-738. https://doi.org/10.1093/petrology/36.3.707

Powell, R., \& Holland, T. J. B. (1988). An internally consistent thermodynamic dataset with uncertainties and correlations. 3. Application, methods, worked examples and a computer program. Journal of Metamorphic Geology, 6(2), 173-204. https://doi. org/10.1111/j.1525-1314.1988.tb00415.x

Powell, R., Holland, T. J. B., \& Worley, B. A. (2004). Calculating phase diagrams involving solid solutions via non-linear equations, with examples using THERMOCALC. Journal of Metamorphic Geology, 16(4), 577-588. https://doi.org/10.1111/j.1525-1314.1998.00157.x

Price, R. C., \& Taylor, S. R. (1977). The rare earth element geochemistry of granite, gneiss, and migmatite from the western metamorphic belt of south-eastern Australia. Contributions to Mineralogy and Petrology, 62(3), 249-263. https://doi.org/10.1007/BF00371013

Rivers, T. (2008). Assembly and preservation of lower, mid, and upper orogenic crust in the Grenville Province-Implications for the evolution of large hot long-duration orogens. Precambrian Research, 167(3-4), 237-259. https://doi.org/10.1016/j.precamres.2008.08.005

Rivers, T., Clushaw, N., Hynes, A., Indares, A., Jamieson, R., \& Martignole, J. (2012). The Grenville Orogen-A post-lithoprobe perspective. Tectonic Styles in Canada: The LITHOPROBE Perspective: Geological Association of Canada Special Paper, 49, 97-236.

Rocha, B. C., Moraes, R., Möller, A., Cioffi, C. R., \& Jercinovic, M. J. (2017). Timing of anatexis and melt crystallization in the SocorroGuaxupé Nappe, SE. Brazil: Insights from trace element composition of zircon, monazite and garnet coupled to U-Pb geochronology. Lithos, 277, 337-355. https://doi.org/10.1016/j.lithos.2016.05.020

Rosenberg, C. L., \& Handy, M. R. (2000). Syntectonic melt pathways during simple shearing of a partially molten rock analogue (Norcamphor-Benzamide). Journal of Geophysical Research, 105, 3135-3149. https://doi.org/10.1029/1999JB900371

Rutter, E. H., \& Neumann, D. H. K. (1995). Experimental deformation of partially molten Westerly granite under fluid-absent conditions, with implications for the extraction of granitic magmas. Journal of Geophysical Research, 100, 15697-15715. https://doi. org/10.1029/94JB03388

Sawyer,E.W.(2001). Melt segregation in the continental crust: Distribution and movement of melt in anatectic rocks. Journal of Metamorphic Geology, 19(3), 291-309. https://doi.org/10.1046/j.0263-4929.2000.00312.x

Sawyer, E. W. (2008). Atlas of migmatites. NRC Research Press, 9 , 137-141.

Sawyer, E. W. (2014). The inception and growth of leucosomes: Microstructure at the start of melt segregation in migmatites. Journal of Metamorphic Geology, 32(7), 695-712. https://doi. org/10.1111/jmg.12088
Sawyer, E. W., Cesare, B., \& Brown, M. (2011). When the continental crust melts. Elements, 7(4), 229-234. https://doi.org/10.2113/ gselements.7.4.229

Simakin, A., \& Talbot, C. (2001). Transfer of melt between microscopic pores and macroscopic veins in migmatites. Physics and Chemistry of the Earth, Part A: Solid Earth and Geodesy, 26(4-5), 363-367. https://doi.org/10.1016/s1464-1895(01),00066-7

Skjerlie, K. P., Patino Douce, A. E., \& Johnston, A. D. (1993). Fluid absent melting of a layered crustal protolith: Implications for the generation of anatectic granites. Contributions to Mineralogy and Petrology, 114(3), 365-378. https://doi.org/10.1007/BF01046539

Stevenson, D. (1989). Spontaneous small-scale melt segregation in partial melts undergoing deformation. Geophysical Research Letters, 16(9), 1067-1070. https://doi.org/10.1029/GL016i009p01067

Troll, G., \& Winter, H. (1983). The chemical composition of biotite from anatectites and their metabasitic inclusions, Bayerischer-Wald, Eastern Bavaria. Neues Jahrbuch fur Minerlogie Abhandlungen, 146, 117-132.

Weinberg, R. F., Hasalová, P., Ward, L., \& Fanning, C. M. (2013). Interaction between deformation and magma extraction in migmatites: Examples from Kangaroo Island, South Australia. Geological Society of America Bulletin, 125(7-8), 1282-1300. https://doi. org/10.1130/B30781.1

Weinberg, R. F., \& Mark, G. (2008). Magma migration, folding, and disaggregation of migmatites in the Karakoram Shear Zone, Ladakh, NW India. Geological Society of America Bulletin, 120(7-8), 9941009. https://doi.org/10.1130/B26227.1

White, R. W., \& Powell, R. (2010). Retrograde melt-residue interaction and the formation of near-anhydrous leucosomes in migmatites. Journal of Metamorphic Geology, 28(6), 579-597. https://doi. org/10.1111/j.1525-1314.2010.00881.x

White, R. W., Powell, R., \& Baldwin, J. A. (2008). Calculated phase equilibria involving chemical potentials to investigate the textural evolution of metamorphic rocks. Journal of Metamorphic Geology, 26(2), 181-198. https://doi. org/10.1111/j.1525-1314.2008.00764.x

White, R. W., Powell, R., \& Holland, T. J. B. (2007). Progress relating to calculation of partial melting equilibria for metapelites. Journal of Metamorphic Geology, 25(5), 511-527. https://doi. org/10.1111/j.1525-1314.2007.00711.x

White, R. W., Powell, R., Holland, T. J. B., Johnson, T. E., \& Green, E. C. R. (2014). New mineral activity-composition relations for thermodynamic calculations in metapelitic systems. Journal of Metamorphic Geology, 32(3), 261-286. https://doi.org/10.1111/jmg.12071

Whitney, D. L., \& Evans, B. W. (2010). Abbreviations for names of rock-forming minerals. American Mineralogist, 95(1), 185-187. https://doi.org/10.2138/am.2010.3371

Wickham, S. M. (1987). The segregation and emplacement of granitic melts. Geological Society of London Journal, 144(2), 281-297. https://doi.org/10.1144/gsjgs.144.2.0281

Wynne-Edwards, H. R., Price, R. A., \& Douglas, R. J. W. (1972). The Grenville Province. Variations in Tectonic Styles in Canada: Geological Association of Canada Special Publication, 11, 263-334.

\section{SUPPORTING INFORMATION}

Additional supporting information may be found online in the Supporting Information section at the end of the article. 
Table S1. Whole-rock composition.

Table S2. Mineral chemistry.

Table S3. Trace element concentration of biotite from LA-QICP-MS analyses.

Table S4. Small-scale whole-rock composition from area analyses using Micro-XRF.

Table S5. Small-scale whole-rock composition from LA-QICP-MS raster analyses.

Appendix S1. Analytical methods.
How to cite this article: Lin L, Sawyer EW.

Microstructure and compositional changes across biotite-rich reaction selvedges around mafic schollen in a semipelitic diatexite migmatite. J Metamorph Geol. 2019;37:539-566. https://doi.org/10.1111/ jimg. 12475 